\title{
Towards the Forest Virome: High-Throughput Sequencing Drastically Expands Our Understanding on Virosphere in Temperate Forest Ecosystems
}

\author{
Artemis Rumbou ${ }^{1, *(D)}$, Eeva J. Vainio ${ }^{2}$ and Carmen Büttner $^{1}$ (D) \\ 1 Faculty of Life Sciences, Albrecht Daniel Thaer-Institute of Agricultural and Horticultural Sciences, \\ Humboldt-Universität zu Berlin, 14195 Berlin, Germany; carmen.buettner@agrar.hu-berlin.de \\ 2 Natural Resources Institute Finland, Forest Health and Biodiversity, Latokartanonkaari 9, \\ 00790 Helsinki, Finland; eeva.vainio@luke.fi \\ * Correspondence: artemis.rumbou@agrar.hu-berlin.de
}

check for updates

Citation: Rumbou, A.; Vainio, E.J.; Büttner, C. Towards the Forest

Virome: High-Throughput

Sequencing Drastically Expands Our

Understanding on Virosphere in

Temperate Forest Ecosystems.

Microorganisms 2021, 9, 1730.

https://doi.org/10.3390/

microorganisms 9081730

Academic Editor: Felix Broecker

Received: 20 June 2021

Accepted: 11 August 2021

Published: 14 August 2021

Publisher's Note: MDPI stays neutral with regard to jurisdictional claims in published maps and institutional affiliations.

Copyright: (c) 2021 by the authors. Licensee MDPI, Basel, Switzerland. This article is an open access article distributed under the terms and conditions of the Creative Commons Attribution (CC BY) license (https:/ / creativecommons.org/licenses/by/ $4.0 /)$.

\begin{abstract}
Thanks to the development of HTS technologies, a vast amount of genetic information on the virosphere of temperate forests has been gained in the last seven years. To estimate the qualitative/quantitative impact of HTS on forest virology, we have summarized viruses affecting major tree/shrub species and their fungal associates, including fungal plant pathogens, mutualists and saprotrophs. The contribution of HTS methods is extremely significant for forest virology. Reviewed data on viral presence in holobionts allowed us a first attempt to address the role of virome in holobionts. Forest health is dependent on the variability of microorganisms interacting with the host tree/holobiont; symbiotic microbiota and pathogens engage in a permanent interplay, which influences the host. Through virus-virus interplays synergistic or antagonistic relations may evolve, which may drastically affect the health of the holobiont. Novel insights of these interplays may allow practical applications for forest plant protection based on endophytes and mycovirus biocontrol agents. The current analysis is conceived in light of the prospect that novel viruses may initiate an emergent infectious disease and that measures for the avoidance of future outbreaks in forests should be considered.
\end{abstract}

Keywords: forest virome; high-throughput sequencing; mycoviruses; plant pathogenic viruses

\section{Introduction}

Forests represent a major natural resource and provider of ecosystem services, products and jobs in Europe. They cover 35\% of Europe's total land area [1], their ecological importance being as significant as their economic importance. The majority of the countries have $30-45 \%$ of their land area covered with forests, while countries in northern Europe have larger forest areas, with three-quarters of the total land area in Finland and 69\% in Sweden being covered by forests. The forest sector, consisting of the wood and paper industries contributes $1.97 \%$ of the total gross domestic product (GDP) in northern Europe and on average $0.72 \%$ of the total GDP of Europe [1,2]. Pests and diseases have been reported as important causes of damage among wildlife and grazing by domestic animals, fires and weather extremes, such as storms. Insect attacks, weather extremes and fungal diseases have been reported as the most common and widespread factors associated with tree defoliation [1]. Forest health is a "public good", and multiple categories of end-users may benefit from it. The forest industry, seed producers, nurseries, producers of nontimber products and the broader society are end-users of forests and urban green areas as providers of multiple ecosystem services. The need of indicators to provide information on forest ecosystem health and vitality, which may enable an evaluation of its resilience, is clearly underlined [2].

Land plants are known to own a virome of a distinct composition, heavily dominated by diverse positive sense RNA $((+)$ RNA) viruses, with a more limited representa- 
tion of double-stranded RNA (dsRNA), negative sense RNA ((-)RNA) viruses, reversetranscribing (RT) viruses and single-stranded DNA (ssDNA) viruses, to the exclusion of bona fide dsDNA viruses [3]. The virome of land plants fits into two of the four realms, Riboviria-into which the majority of plant virome diversity fits-and Monodnaviria. Within Riboviria, two kingdoms are included. The first kingdom is Orthornavirae and harbors the bona fide RNA viruses with no DNA stage in their replication cycles and replication modules organized around the RNA-dependent RNA polymerase (RdRP). The second kingdom, Pararnavira, consists of reverse-transcribing viruses encoding a reverse transcriptase (RT), which is homologous to the RdRPs of RNA viruses. Viruses with ssDNA genomes encoding rolling-circle replication endonucleases (RCRE) of the HUH superfamily are classified into the realm Monodnaviria. The virome of fungi has a similar composition, lacking dsDNA viruses as well but exhibiting a bias toward dsRNA viruses [4]. According to the status of knowledge when the review of Ghabrial et al. [4] was published, fungal viruses made of linear dsRNA were classified into seven families: Chryso-, Endorna- Megabirna-, Quadri-, Partiti-, Reo- and Totiviridae. The linear (+)ssRNA viruses were classified into five families: Alphaflexi-, Barna-, Gammaflexi-, Hypo- and Narnaviridae. The linear (-)ssRNA belonged to the proposed family "Mycomononegaviridae", while the circular ssDNA viruses were still unclassified.

Virus diseases of forest tree species represent a threat for the forest health that has been underestimated thus far $[5,6]$. Unfortunately, numerical data on the losses from virus diseased forest trees are lacking, but they are definitely assumed to be considerable based on experience from virus infection on fruit trees, while current data on symptom appearance, disease dispersal and epidemic severity provide essential evidence of this. Forest tree viruses are ranking highly in regard to their risk for introduction and establishment in forests and crops, and this lies mainly upon the wide distribution of susceptible plant germplasm, the often extended host range and the rapid emergence of new genotypes (virus strains or variants). Most common reports in the Program for Monitoring Emerging Diseases (ProMED) run by the International Society for Infectious Diseases (ISID) are reports of newly arrived viruses and viroids (36.6\%) among approximately 140 emerging infectious diseases (EIDs) in plants [7]. From our own investigations and existing references, we suggest that viruses remarkably contribute to emerging infectious diseases and confirm Büttner and Nienhaus [5] who raised awareness of the issue in the 1980s.

Due to the utilization of high-throughput sequencing (HTS) methodologies, forest virology has gained a significant momentum in identifying viruses-infecting forest trees and associated fungi [8-11]. These platforms offer the possibility of metagenomic analysis, the study of microbial populations in samples by analyzing their nucleotide sequence content. RNA viruses, viroids and the RNA stages of actively replicating DNA viruses can be directly sequenced. Among HTS platforms employed, RNA-Seq and double-stranded RNA (dsRNA) sequencing of affected plant or fungal cells were most commonly applied; there were also, however, some cases where air metagenomis was performed or data were retrieved from a transcriptome shotgun assembly. Concretely, the investigation of a serious epidemic related to the birch leaf-roll disease (BLRD) in Betula spp. in Europe $[12,13]$ represents a recent example of HTS application in forest virology. Employing RNA-Seq, birch viromes in relation with BLRD were unraveled revealing a complex of novel and known viruses (Badna-, Nepo- and Capillovirus) [14], while a novel badna virus was associated with the BLRD symptoms and was genetically characterized [15]. Another current viral epidemic in Europe is correlated with the European mountain ash ringspot-associated virus (EMARaV) of the genus Emaravirus within the family Fimoviridae, which is the causal agent of the "European mountain ash ringspot disease" in Sorbus aucuparia [16,17]. Regarding EMARaV, it was initially reported only in European mountain ash; lately, however, and with the use of HTS, several emaraviruses have been detected in new hosts, such as Karpatiosorbus x hybrid in Finland [18], Sorbus intermedia in Sweden [19] and Amelanchier spp. in Germany [20]. 
Regarding mycoviruses, a significant amount of data derive from the last decade through metagenomic analyses [21]. These viruses were not targeted earlier as, based on the traditional principles of phytopathology, they were not considered as non-plant pathogens. Viruses of the family Partitiviridae have also been largely ignored as they maintain a persistent lifestyle and they do not generally cause plant diseases. These are characterized by vertical transmission through seeds and/or pollen and a lack of pathogenicity and infectivity (ability to infect new hosts de novo via plant-to-plant transmission) [22]. The tree host in this review is considered as a holobiont, defined as the tree/shrub organism and all its microbiome, explicitly, symbiotic microbiota and pathogenic fraction (bacteria, oomycetes, protists and viruses) (definition by Margulis, 1993; [23]). Viruses that reduce the pathogenicity or growth of fungal plant pathogens can be considered beneficial for the holobiont, as they protect the tree from disease. In turn, viruses that would cause the debilitation of mutualistic mycorrhizal fungi are harmful from the viewpoint of the host plant. Therefore, mycoviruses will be addressed here based on the ecological guild of the host fungus: viruses of plant pathogens and viruses of mutualistic fungi.

This review aims to describe and comprehend the current status of the virosphere of a forest by summarizing the viral species coexisting in a forest. We name this "forest virome" and consider all existing genetic information of viral origin to be related to common forest trees and shrubs. Although the interactions between the host and viral agent are not always adequately defined, we have considered the following categories of interactions: a. pathogenic virus versus tree/shrub host, b. non-pathogenic virus versus tree/shrub host, c. pathogenic virus versus fungal host or d. non-pathogenic virus versus fungal host. In the term "forest", we consider the natural temperate and boreal forest ecosystems in the Northern Hemisphere as well as urban parks and urban green areas mainly covered by forest trees and shrubs, which constitute separate ecosystems within urban environments. However, it is beyond the aim of the present review to list all studies performed to date; this work has been thoroughly carried out previously [6]. The aim of the present work is to update the list of pathogens considered as present in the forest ecosystem in light of the sequencing efforts and discoveries achieved in the last seven years. Regarding our aim to describe the forest virome, here, we do not consider observations that lack genetic characterization and sequence data availability.

The need for a current review about forest viruses is further strengthened by the fact that advances in plant virology are traditionally restricted in crop or fruit tree pathogenic viruses. This becomes apparent when considering the latest reviews [24,25] resuming viral discoveries using deep sequencing techniques in fruit trees, where virus discoveries in the forest ecosystem are not included. It is true that few groups worldwide focus their plant pathology research on forest ecosystems, which may be partially attributed to the difficulties in quantitatively estimating the importance of forest ecosystems and the economic impact due to viral epidemics. Despite this fact, it is shown through the present work that substantial progress has been achieved in this field, and in many cases, this has radically changed our understanding of viral forest diseases.

Finally, this review presents various lines of evidence regarding why further research on forest virome is required in order to a. biologically characterize the newly described pathogens, including their modes of dispersal and possible vectors; $b$. build the knowledge base of virus-tree interactions as well as of virus-fungus interactions; c. gather knowledge on the behavior of the forest parasites, in preparation for future outbreaks as a consequence of significant changes in the climate and the environment; $d$. explore alternative means of controlling fungal and viral forest diseases. As our understanding of the viruses of fungal endophytes and forest pathogens is only at the very beginning, it is an ideal time to apply the most modern sequenced-based tools in favor of forest virology.

\section{Interaction of Viral Agents with Other Organisms}

The current analysis was based on two main principles. The first was the hologenome theory of evolution [26,27]. According to this theory, a holobiont is a single dynamic entity 
in which a vast amount of its genetic information and variability is contributed by the microorganisms [28]. In this study, we considered a forest tree/shrub as a holobiont and focused on a part of its microbiome, the virome, considering all virus communities (as dependent biological agents) a. affecting the tree (plant pathogenic or latent viruses) and b. affecting the exosymbionts and endosymbionts of the tree (mycoviruses). The second principle was that "forest" was considered as an ecosystem with multiple holobionts (diverse tree species); our focus was put on the viral variation that characterizes the whole system, and this we called the "forest virome".

To explore the studies involved in the described subject, we first listed viruses alphabetically, ordering them in three categories: 1. plant viruses infecting tree/shrub hosts and cryptoviruses (Table 1), 2. mycoviruses occurring in plant pathogenic fungi (Table 2) and 3. mycoviruses occurring in mutualistic fungi and saprotrophs (Table 3). To systematically handle the data, we listed in the following section the 11 most important forest tree or shrub genera known to be affected by viruses; a separate section is devoted to the virome of each plant genus (Sections 3.1-3.11. Another section is devoted to "other trees", where less information is available thus far (Section 3.12). For all searches to detect all related articles, the search-machine of Elsevier's Scopus, a large citation database of peer-reviewed literature, was applied (www.scopus.com/search/; accessed on 20 June 2021).

Table 1. Plant viruses infecting tree/shrub hosts and cryptoviruses. For each virus, the virus name, genus and family name, virus tree/shrub host(s), countries in which the virus was reported and the related references are given. Numbers in the first column represent ordinal numbers of the listed viruses. Viruses that were discovered by means of HTS methods are indicated by the note "HTS" next to their ordinal number.

\begin{tabular}{|c|c|c|c|c|c|}
\hline & Virus Name & Genus, Family Name & Host Name (s) & Distribution $^{+}$ & References \\
\hline 1 & $\begin{array}{l}\text { apple chlorotic leaf } \\
\text { spot virus } \\
\text { (ACLSV) }\end{array}$ & $\begin{array}{c}\text { Trichovirus, Beta- } \\
\text { flexiviridae } \\
(+) \text { ssRNA }\end{array}$ & $\begin{array}{c}\text { Aesculus } \\
\text { hippocastanum, } \\
\text { S. aucuparia }\end{array}$ & UK, Germany & {$[6,29]$} \\
\hline 2 & $\begin{array}{l}\text { apple mosaic virus } \\
(\mathrm{ApMV})\end{array}$ & $\begin{array}{c}\text { Ilarvirus, Bromoviridae } \\
(+) \text { ssRNA }\end{array}$ & $\begin{array}{l}\text { Carpinus, Sorbus, } \\
\text { Aesculus, Betula }\end{array}$ & $\begin{array}{l}\text { Canada, } \\
\text { Europe }\end{array}$ & $\begin{array}{c}\text { [30,31](Sorbus, } \\
\text { Aesculus, Betula, } \\
\text { Carpinus); [32] (Betula); } \\
\text { [33] (Rubus); [34] }\end{array}$ \\
\hline 3 & $\begin{array}{l}\text { arabis mosaic virus } \\
\text { (ArMV) }\end{array}$ & $\begin{array}{c}\text { Nepovirus, Seco- } \\
\text { viridae } \\
(+) \text { ssRNA }\end{array}$ & $\begin{array}{l}\text { Acer, Fraxinus, } \\
\text { Populus, Rubus, } \\
\text { Betula }\end{array}$ & Europe, USA & $\begin{array}{c}\text { [35] (Betula), [36] } \\
\text { (Populus); } \\
{[37,38] \text { (Fraxinus); [39] }} \\
\text { (Rubus); [40,41] (Acer) }\end{array}$ \\
\hline $\begin{array}{c}4 \\
\text { HTS }\end{array}$ & $\begin{array}{c}\text { aspen } \\
\text { mosaic-associated } \\
\text { virus }(\mathrm{AsMaV})\end{array}$ & $\begin{array}{c}\text { Emaravirus, Fimo- } \\
\text { viridae } \\
(-) \text { ssRNA }\end{array}$ & Populus tremula & Germany & [42] \\
\hline $\begin{array}{c}5 \\
\text { HTS }\end{array}$ & $\begin{array}{c}\text { birch } \\
\text { leafroll-associated } \\
\text { virus (BLRaV) }\end{array}$ & $\begin{array}{c}\text { Badnavirus, Cauli- } \\
\text { moviridae } \\
\text { RT virus }\end{array}$ & Betula & $\begin{array}{l}\text { Germany, } \\
\text { Finland }\end{array}$ & {$[14,15]$} \\
\hline $\begin{array}{c}6 \\
\text { HTS }\end{array}$ & $\begin{array}{l}\text { birch idaeovirus } \\
\text { (BIV) }\end{array}$ & $\begin{array}{c}\text { Idaeovirus, Mayoviridae } \\
(+) \text { ssRNA }\end{array}$ & Betula & Germany & [14] \\
\hline $\begin{array}{c}7 \\
\text { HTS }\end{array}$ & $\begin{array}{l}\text { birch capillovirus } \\
\text { (BCV) }\end{array}$ & $\begin{array}{c}\text { Capillovirus, } \\
\text { Betaflexiviridae } \\
(+) \text { ssRNA }\end{array}$ & Betula & Germany & [14] \\
\hline $\begin{array}{c}8 \\
\text { HTS }\end{array}$ & $\begin{array}{l}\text { birch carlavirus } \\
\text { (BiCV) }\end{array}$ & $\begin{array}{c}\text { Carlavirus, } \\
\text { Betaflexiviridae }(+) \text { ssRNA }\end{array}$ & Betula & Germany & [14] \\
\hline 9 & $\begin{array}{l}\text { blueberry scorch } \\
\text { virus }(\mathrm{BlScV})\end{array}$ & $\begin{array}{l}\text { Carlavirus, Betafle- } \\
\text { xiviridae }(+) \text { ssRNA }\end{array}$ & Sambucus nigra & Poland & {$[43,44]$} \\
\hline
\end{tabular}


Table 1. Cont.

\begin{tabular}{|c|c|c|c|c|c|}
\hline & Virus Name & Genus, Family Name & Host Name (s) & Distribution ${ }^{+}$ & References \\
\hline 10 & $\begin{array}{l}\text { Brome mosaic } \\
\text { virus (BMV) }\end{array}$ & $\begin{array}{c}\text { bromovirus, Bromoviridae } \\
(+) \text { ssRNA }\end{array}$ & Salix & & [45] \\
\hline 11 & $\begin{array}{l}\text { cherry leaf roll } \\
\text { virus (CLRV) }\end{array}$ & $\begin{array}{c}\text { Nepovirus, Secoviridae } \\
(+) \text { ssRNA }\end{array}$ & $\begin{array}{l}\text { Betula, Aesculus, } \\
\text { Fagus, Fraxinus, } \\
\text { Sambucus, Sorbus, } \\
\text { Ulmus armeniaca }\end{array}$ & Europe, USA & $\begin{array}{c}\text { [6] (Fagus); [46] } \\
\text { (Betula); } \\
\text { [29] (Aesculus); [47] } \\
\text { (Fraxinus); [13,48] } \\
\text { (Betula); [49,50] } \\
\text { (Sambucus); [51] } \\
\text { (Sambucus nigra, } \\
\text { Sorbus); [52] (Ulmus } \\
\text { armeniaca, Fagus); [53] }\end{array}$ \\
\hline 12 & $\begin{array}{l}\text { cherry rasp leaf } \\
\text { virus (ChRLV) }\end{array}$ & $\begin{array}{c}\text { Cheravirus, Secoviridae } \\
(+) \text { ssRNA }\end{array}$ & $\begin{array}{l}\text { Sambucus nigra } \\
\text { subsp. caerulea, }\end{array}$ & USA & [54] \\
\hline $\begin{array}{c}13 \\
\text { HTS }\end{array}$ & $\begin{array}{l}\text { chestnut mosaic } \\
\text { virus (ChMV) }\end{array}$ & $\begin{array}{c}\text { Badnavirus, Cauli- } \\
\text { moviridae } \\
\text { RT virus }\end{array}$ & Castanea sativa & Italy, France & [55] \\
\hline $\begin{array}{c}14 \\
\text { HTS }\end{array}$ & $\begin{array}{l}\text { common oak } \\
\text { ringspot- } \\
\text { associated virus } \\
(\mathrm{CORaV})\end{array}$ & $\begin{array}{c}\text { Emaravirus, Fimoviridae } \\
(-) \text { ssRNA }\end{array}$ & Quercus robur & Germany & {$[56,57]$} \\
\hline $\begin{array}{c}15 \\
\text { HTS }\end{array}$ & $\begin{array}{c}\text { elderberry } \\
\text { aureusvirus } 1 \\
\text { (ElAV1) }\end{array}$ & $\begin{array}{c}\text { Aureusvirus, } \\
\text { Tombusviridae } \\
\text { (+)ssRNA }\end{array}$ & Sambucus nigra & Czech Republic & [58] \\
\hline 16-20 HTS & $\begin{array}{c}\text { elderberry } \\
\text { carlaviruses } \\
\text { A,B,C,D,E } \\
\text { (ElVA-ElVE) }\end{array}$ & $\begin{array}{l}\text { Carlavirus, } \\
\text { Betaflexiviridae } \\
(+) \text { ssRNA }\end{array}$ & Sambucus nigra & USA & {$[59,60]$} \\
\hline $\begin{array}{c}21 \\
\text { HTS }\end{array}$ & $\begin{array}{l}\text { elm carlavirus } \\
(\mathrm{ECV})\end{array}$ & $\begin{array}{l}\text { Carlavirus, } \\
\text { Betaflexiviridae } \\
(+) \text { ssRNA }\end{array}$ & Ulmus laevis & Germany & [61-63] \\
\hline 22 & $\begin{array}{l}\text { elderberry latent } \\
\text { virus (ELV) }\end{array}$ & $\begin{array}{c}\text { Pelarspovirus, } \\
\text { Tombusviridae } \\
\text { (+)ssRNA }\end{array}$ & $\begin{array}{l}\text { Sambucus nigra, } S . \\
\text { canadensis }\end{array}$ & $\begin{array}{c}\text { Austria, } \\
\text { Poland, USA }\end{array}$ & {$[49,59]$} \\
\hline 23 & $\begin{array}{l}\text { elm mottle virus } \\
(\text { EMoV) }\end{array}$ & $\begin{array}{c}\text { Ilarvirus, Bromoviridae } \\
(+) \text { ssRNA }\end{array}$ & Ulmus & $\begin{array}{l}\text { central Europe, } \\
\text { Russia, UK }\end{array}$ & [64-66] \\
\hline $\begin{array}{c}24 \\
\text { HTS }\end{array}$ & $\begin{array}{c}\text { European } \\
\text { mountain ash } \\
\text { ringspot- } \\
\text { associated virus } \\
\text { (EMARaV) }\end{array}$ & $\begin{array}{c}\text { Emaravirus, Fimoviridae } \\
(-) \text { ssRNA }\end{array}$ & $\begin{array}{c}\text { Sorbus aucuparia, } \\
\text { Aronia melanocarpa, } \\
\text { Amelanchier, } \\
\text { Karpatiosorbus } \times \\
\text { hybrid, S. intermedia }\end{array}$ & $\begin{array}{l}\text { Germany, } \\
\text { Finland, } \\
\text { Czech } \\
\text { Republic, } \\
\text { UK, } \\
\text { Russia, } \\
\text { Sweden, } \\
\text { Poland, } \\
\text { Norway }\end{array}$ & $\begin{array}{c}{[67] ;} \\
{[18] ;} \\
{[68] ;} \\
{[17,69] ;} \\
{[70] ;} \\
{[19,71] ;} \\
{[72] ;} \\
{[73] ;}\end{array}$ \\
\hline $\begin{array}{c}25 \\
\text { HTS }\end{array}$ & $\begin{array}{c}\text { maple } \\
\text { mottle-associated } \\
\text { virus }\end{array}$ & $\begin{array}{c}\text { Emaravirus, Fimoviridae } \\
(-) \text { ssRNA }\end{array}$ & Acer pseudoplatanus & Germany & [74] \\
\hline 26 & $\begin{array}{l}\text { peanut stunt virus } \\
\text { (PSV) }\end{array}$ & $\begin{array}{c}\text { Cucumovirus, } \\
\text { Bromoviridae } \\
(+) \text { ssRNA }\end{array}$ & $\begin{array}{c}\text { Robinia } \\
\text { pseudoacacia }\end{array}$ & $\begin{array}{l}\text { Croatia, Italy, } \\
\text { Iran }\end{array}$ & [75-78] \\
\hline $\begin{array}{c}27 \\
\text { HTS }\end{array}$ & $\begin{array}{c}\text { Pinus nigra virus } 1 \\
\text { (PnV1) }\end{array}$ & $\begin{array}{c}\text { unclass. Caulimoviridae } \\
\text { RT virus }\end{array}$ & $\begin{array}{c}\text { air samples, Pinus } \\
\text { nigra }\end{array}$ & Spain & [79] \\
\hline $\begin{array}{l}28 \\
\text { HTS }\end{array}$ & $\begin{array}{l}\text { Pinus patula } \\
\text { amalgavirus } 1\end{array}$ & $\begin{array}{c}\text { unclass. Amalgaviridae } \\
\text { dsRNA }\end{array}$ & Pinus patula & TSA database & [80] \\
\hline 29 & $\begin{array}{l}\text { Pinus sylvestris } \\
\text { partitivirus } \\
\text { NL-2005 }\end{array}$ & $\begin{array}{c}\text { put. Cryptovirus, } \\
\text { unclass. Partitiviridae } \\
\text { dsRNA }\end{array}$ & Pinus sylvestris & Germany & [81] \\
\hline
\end{tabular}


Table 1. Cont.

\begin{tabular}{|c|c|c|c|c|c|}
\hline & Virus Name & Genus, Family Name & Host Name (s) & Distribution $^{+}$ & References \\
\hline 30 & $\begin{array}{l}\text { poplar mosaic } \\
\text { virus (PopMV) }\end{array}$ & $\begin{array}{c}\text { Carlavirus, Betafle- } \\
\text { xiviridae } \\
(+) \text { ssRNA }\end{array}$ & Populus & UK, Germany & [82-84] \\
\hline $\begin{array}{c}31 \\
\text { HTS }\end{array}$ & $\begin{array}{c}\text { Sambucus virus S } \\
\text { (SVS) }\end{array}$ & $\begin{array}{c}\text { Bromovirus, Bromo- } \\
\text { viridae } \\
(+) \text { ssRNA }\end{array}$ & Sambucus nigra & Czech Republic & [85] \\
\hline 32 & $\begin{array}{l}\text { strawberry latent } \\
\text { ringspot virus } \\
\text { (SLRV) }\end{array}$ & $\begin{array}{c}\text { Stralarivirus,Secoviridae } \\
(+) \text { ssRNA }\end{array}$ & $\begin{array}{c}\text { Aesculus } \\
\text { hippocastanum, } \\
\text { Robinia pseu- } \\
\text { doacacia }\end{array}$ & $\begin{array}{l}\text { Germany, } \\
\text { Poland }\end{array}$ & [86-89] \\
\hline 33 & $\begin{array}{l}\text { tomato black ring } \\
\text { virus (ToBRV) }\end{array}$ & $\begin{array}{c}\text { Nepovirus, Secoviridae } \\
(+) \text { ssRNA }\end{array}$ & $\begin{array}{l}\text { Sambucus nigra, } \\
\text { Populus }\end{array}$ & UK, Poland & {$[36,90]$} \\
\hline 34 & $\begin{array}{l}\text { tomato bushy } \\
\text { stunt virus (TBSV) }\end{array}$ & $\begin{array}{c}\text { Tombusvirus, } \\
\text { Tombusviridae } \\
(+) \text { ssRNA }\end{array}$ & $\begin{array}{l}\text { Sambucus nigra, } \\
\text { S. canadensis }\end{array}$ & $\begin{array}{l}\text { USA, Czech } \\
\text { Republic }\end{array}$ & {$[91,92]$} \\
\hline 35 & $\begin{array}{l}\text { tomato mosaic } \\
\text { virus (ToMV) }\end{array}$ & $\begin{array}{c}\text { Tobamovirus, Virgaviridae } \\
(+) \text { ssRNA }\end{array}$ & $\begin{array}{l}\text { Picea rubens, } P . \\
\text { mariana, Abies } \\
\text { balsamea, Salix }\end{array}$ & Canada, USA & {$[45,93,94]$} \\
\hline 36 & $\begin{array}{l}\text { tomato ringspot } \\
\text { virus (ToRSV) }\end{array}$ & $\begin{array}{l}\text { Nepovirus, } \\
\text { Secoviridae } \\
(+) \text { ssRNA }\end{array}$ & $\begin{array}{c}\text { Betula, Fraxinus, } \\
\text { Populus, } \\
\text { Ulmus americana }\end{array}$ & UK, USA & {$[35,36,95,96]$} \\
\hline 37 & $\begin{array}{l}\text { tobacco mocaic } \\
\text { virus (TMV) }\end{array}$ & $\begin{array}{c}\text { Tobamovirus, Virgaviridae } \\
(+) \text { ssRNA }\end{array}$ & Fraxinus, Quercus & $\begin{array}{l}\text { USA, Hungary, } \\
\text { Germany }\end{array}$ & [97-104] \\
\hline 38 & $\begin{array}{l}\text { tobacco necrosis } \\
\text { virus }(\mathrm{TNV})\end{array}$ & $\begin{array}{l}\text { Alphanecrovirus, } \\
\text { Tombusviridae, } \\
(+) \text { ssRNA }\end{array}$ & $\begin{array}{c}\text { Betula, Fagus, } \\
\text { Fraxinus,Pinus, } \\
\text { Quercus, Sambucus } \\
\text { nigra }\end{array}$ & Europe & {$[5,35,91,105,106]$} \\
\hline 39 & $\begin{array}{l}\text { tobacco rattle virus } \\
\text { (TRV) }\end{array}$ & $\begin{array}{c}\text { Tobravirus, Virgaviridae } \\
(+) \text { ssRNA }\end{array}$ & Fraxinus, Populus & Germany & {$[107,108]$} \\
\hline 40 & $\begin{array}{l}\text { tobacco ringspot } \\
\text { virus (TRSV) }\end{array}$ & $\begin{array}{c}\text { Nepovirus Secoviridae } \\
(+) \text { ssRNA }\end{array}$ & $\begin{array}{c}\text { Fraxinus, } \\
\text { Sambucus nigra }\end{array}$ & USA & {$[38,98,99,108-112]$} \\
\hline 41 & $\begin{array}{l}\text { white ash mosaic } \\
\text { virus (WAMV) }\end{array}$ & $\begin{array}{c}\text { unclassified Flexiviridae } \\
(+) \text { ssRNA }\end{array}$ & Fraxinus americana & USA & {$[113,114]$} \\
\hline $\begin{array}{c}42 \\
\text { HTS }\end{array}$ & $\begin{array}{l}\text { putative } \\
\text { cryptovirus }\end{array}$ & $\begin{array}{c}\text { Partitiviridae } \\
\text { dsRNA }\end{array}$ & Fraxinus americana & & [115] \\
\hline $\begin{array}{c}43 \\
\text { HTS }\end{array}$ & $\begin{array}{c}\text { putative } \\
\text { caulimovirus }\end{array}$ & $\begin{array}{l}\text { Caulimoviridae } \\
\text { RT virus }\end{array}$ & Fraxinus americana & & [115] \\
\hline
\end{tabular}

+ The virus distribution data were retrieved from the Invasive Species Compendium CABI in combination with information from the publications referred to in the present review.

Table 2. Mycoviruses occurring in plant pathogenic fungi. For each virus, the virus name, genus and family name, fungal host(s), tree species, countries in which the virus was reported and the related references are given. Numbers in the first column represent ordinal numbers of the listed viruses. Viruses that were discovered by means of HTS methods are indicated by the note "HTS" next to their ordinal number.

\begin{tabular}{|c|c|c|c|c|c|c|}
\hline & Virus Name & $\begin{array}{c}\text { Genus, Family } \\
\text { Name }\end{array}$ & Fungal Host (s) & Tree Host & Distribution ${ }^{+}$ & References \\
\hline $\begin{array}{c}1 \\
\mathrm{HTS}\end{array}$ & $\begin{array}{c}\text { Armillaria borealis } \\
\text { mycovirgavirus } 1 \\
\text { (AbMV1) }\end{array}$ & $\begin{array}{c}\text { unclass. } \\
\text { Virgaviridae } \\
\text { (+)ssRNA }\end{array}$ & $\begin{array}{c}\text { Armillaria } \\
\text { borealis }\end{array}$ & Populus spp. & Russia & [116] \\
\hline 2-4 HTS & $\begin{array}{c}\text { Armillaria borealis } \\
\text { ambi-like virus 1, }, \\
\text { 3 (AbAlV1-3) }\end{array}$ & $\begin{array}{l}\text { unclass. } \\
\text { Riboviria }\end{array}$ & $\begin{array}{c}\text { Armillaria } \\
\text { borealis }\end{array}$ & Populus spp. & Russia, Finland & [116] \\
\hline $\begin{array}{c}5 \\
\mathrm{HTS}\end{array}$ & $\begin{array}{c}\text { Armillaria mellea } \\
\text { negative strand } \\
\text { RNA virus } 1 \\
\text { (AmNSRV1) }\end{array}$ & $\begin{array}{l}\text { Mymonaviridae } \\
(-) \text { ssRNA }\end{array}$ & Armillaria mellea & Quercus robur & South Africa & [116] \\
\hline
\end{tabular}


Table 2. Cont

\begin{tabular}{|c|c|c|c|c|c|c|}
\hline & Virus Name & $\begin{array}{c}\text { Genus, Family } \\
\text { Name }\end{array}$ & Fungal Host (s) & Tree Host & Distribution $^{+}$ & References \\
\hline $\begin{array}{c}6 \\
\text { HTS }\end{array}$ & $\begin{array}{c}\text { Armillaria mellea } \\
\text { ourmia-like virus } 2 \\
\text { (AmOlV2) }\end{array}$ & $\begin{array}{l}\text { Botourmiaviridae } \\
(+) \text { ssRNA }\end{array}$ & Armillaria mellea & Quercus robur & South Africa & [116] \\
\hline 7-11 HTS & $\begin{array}{l}\text { Cronartium ribicola } \\
\text { mitovirus } 15 \\
\text { (CrMV1-5) }\end{array}$ & $\begin{array}{l}\text { unclass. } \\
\text { Mitovirus, } \\
\text { Mitoviridae } \\
\text { (+)ssRNA }\end{array}$ & $\begin{array}{l}\text { Cronartium } \\
\text { ribicola }\end{array}$ & Pinus strobus & North America & [117] \\
\hline $12-14$ & $\begin{array}{c}\text { Cryphonectria } \\
\text { hypovirus } 1,2,3 \\
(\mathrm{CHV}-1-3)\end{array}$ & $\begin{array}{l}\text { Hypovirus, } \\
\text { Hypoviridae } \\
(+) \text { ssRNA }\end{array}$ & $\begin{array}{l}\text { Cryphonectria } \\
\text { parasitica }\end{array}$ & $\begin{array}{l}\text { Castanea spp., } \\
\text { Aesculus } \\
\text { hippocastanum }\end{array}$ & $\begin{array}{c}\text { England, } \\
\text { Croatia, } \\
\text { Slovenia, } \\
\text { Greece, } \\
\text { Turkey } \\
\text { Slovakia, USA }\end{array}$ & [118-124] \\
\hline $\begin{array}{c}15 \\
\mathrm{HTS}\end{array}$ & $\begin{array}{c}\text { Cryphonectria } \\
\text { parasitica } \\
\text { ambivirus 1- NB631 } \\
(\mathrm{CpaV1})\end{array}$ & $\begin{array}{l}\text { Riboviria; } \\
\text { unclass. } \\
\text { Ambivirus } \\
\text { (-)ssRNA }\end{array}$ & $\begin{array}{l}\text { Cryphonectria } \\
\text { parasitica }\end{array}$ & Castanea sativa & Azerbaijan & [125] \\
\hline 16 & $\begin{array}{l}\text { Cryphonectria } \\
\text { parasitica } \\
\text { mitovirus } 1 \\
\text { (CMV-1-cpNB631) }\end{array}$ & $\begin{array}{l}\text { Mitovirus, } \\
\text { Mitoviridae } \\
(+) \text { ssRNA }\end{array}$ & $\begin{array}{l}\text { Cryphonectria } \\
\text { parasitica }\end{array}$ & Castanea sativa & USA & [126] \\
\hline $\begin{array}{c}17 \\
\mathrm{HTS}\end{array}$ & $\begin{array}{c}\text { Cryphonectria } \\
\text { parasitica } \\
\text { sclerotimonavirus } 1 \\
(\mathrm{CpSV} 1)\end{array}$ & $\begin{array}{l}\text { unclass.Sclerotimo } \\
\text { Mymonaviridae } \\
(-) \text { ssRNA }\end{array}$ & $\begin{array}{l}\text { Cryphonectria } \\
\text { parasitica }\end{array}$ & Castanea sativa & Azerbaijan & [125] \\
\hline 18-20 HTS & $\begin{array}{c}\text { Heterobasidion } \\
\text { mitovirus 1,2,3 } \\
\text { (HetMV1-3) }\end{array}$ & $\begin{array}{l}\text { Mitovirus, } \\
\text { Mitoviridae } \\
(+) \text { ssRNA }\end{array}$ & $\begin{array}{l}\text { H. annosum and } \\
\text { H. parviporum }\end{array}$ & $\begin{array}{l}\text { Pinus sylvestris, } \\
\text { Picea abies }\end{array}$ & $\begin{array}{c}\text { Poland, } \\
\text { Finland, Russia }\end{array}$ & $\begin{array}{c}{[9,127]} \\
{[128]}\end{array}$ \\
\hline 21 & $\begin{array}{l}\text { Heterobasidion } \\
\text { RNA virus } 6 \\
\left(\text { HetRV6 }{ }^{*}\right)\end{array}$ & $\begin{array}{c}\text { Orthocurvulavirus, } \\
\text { Curvulaviridae } \\
\text { dsRNA }\end{array}$ & $\begin{array}{c}\text { Heterobasidion } \\
\text { abietinum, } H . \\
\text { annosum, } H . \\
\text { parviporum, } H . \\
\text { occidentale }\end{array}$ & $\begin{array}{c}\text { Abies alba, } A . \\
\text { sibirica, } A . \\
\text { cephalonica, } A . \\
\text { cilicica, } A \text {. } \\
\text { equi-trojani, } A \text {. } \\
\text { concolor, Pinus } \\
\text { sylvestris, } P \text {. } \\
\text { nigra, } P \text {. obovata, } \\
\text { Picea abies, } \\
\text { Fagus }\end{array}$ & Europe, USA & [129] \\
\hline $22-35$ & $\begin{array}{c}\text { Heterobasidion } \\
\text { partitivirus 1, } 3, \\
4^{*}, 5,9,10,11,12 \\
13^{*}, 14,15,16,20 \\
\text { (HetPV1, } \\
\text { HetPV3-5, } \\
\text { HetPV9-16, } \\
\text { HetPV20) }\end{array}$ & $\begin{array}{c}\text { Alphapartitivirus, } \\
\text { Partitiviridae } \\
\text { dsRNA }\end{array}$ & $\begin{array}{l}\text { Heterobasidion } \\
\text { abietinum, } \\
\text { H. ecrustosum, } \\
\text { H. parviporum, } \\
\text { H. occidentale, } \\
\text { H. australe, } \\
\text { H. annosum, } \\
\text { H. irregulare }\end{array}$ & $\begin{array}{c}\text { Abies } \\
\text { cephalonica, } \\
\text { A. concolor, } \\
\text { Pinus } \\
\text { massoniana, } \\
\text { P. wallichiana, P. } \\
\text { sylvestris, } \\
\text { P. elliottii, } \\
\text { P. abies, P. pinea, } \\
\text { Picea likiangensis }\end{array}$ & $\begin{array}{c}\text { Greece, } \\
\text { China, } \\
\text { Finland, } \\
\text { Italy, } \\
\text { Poland, Russia, } \\
\text { USA, } \\
\text { Bhutan }\end{array}$ & {$[127,130-136]$} \\
\hline $36-38$ & $\begin{array}{c}\text { Heterobasidion } \\
\text { partitivirus } 2 *, 7 * \\
8 \\
\text { (HetPV2-8) }\end{array}$ & $\begin{array}{l}\text { Betapartitivirus, } \\
\text { Partitiviridae } \\
\text { dsRNA }\end{array}$ & $\begin{array}{l}\text { Heterobasidion } \\
\text { parviporum, } H . \\
\text { annosum, } H . \\
\text { irregulare }\end{array}$ & $\begin{array}{c}\text { Picea abies, } P . \\
\text { sylvestris, } P . \\
\text { pinea }\end{array}$ & Finland, Italy & {$[127,134,137]$} \\
\hline 39 & $\begin{array}{c}\text { Hymenoscyphus } \\
\text { fraxineus mitovirus } \\
1 \text { (HfMV1) }\end{array}$ & $\begin{array}{l}\text { unclass. } \\
\text { Mitovirus, } \\
\text { Mitoviridae } \\
(+) \text { ssRNA }\end{array}$ & $\begin{array}{l}\text { Hymenoscyphus } \\
\text { fraxineus }\end{array}$ & Fraxinus spp. & $\begin{array}{l}\text { Switzerland, } \\
\text { Japan, Poland, } \\
\text { Germany, } \\
\text { Lithuania, } \\
\text { Norway }\end{array}$ & [138] \\
\hline
\end{tabular}


Table 2. Cont.

\begin{tabular}{|c|c|c|c|c|c|c|}
\hline & Virus Name & $\begin{array}{c}\text { Genus, Family } \\
\text { Name }\end{array}$ & Fungal Host (s) & Tree Host & Distribution ${ }^{+}$ & References \\
\hline $\begin{array}{l}40-42 \\
\text { HTS }\end{array}$ & $\begin{array}{c}\text { Fusarium } \\
\text { circinatum } \\
\text { mitovirus 1, 2-1 } \\
\text { and 2-2 (FcMV1, } \\
\text { FcMV2-1, } \\
\text { FcMV2-2) }\end{array}$ & $\begin{array}{l}\text { unclass. } \\
\text { Mitovirus, } \\
\text { Mitoviridae } \\
(+) \text { ssRNA }\end{array}$ & $\begin{array}{l}\text { Fusarium } \\
\text { circinatum }\end{array}$ & $\begin{array}{l}\text { Pinus radiate, } P \text {. } \\
\text { pinaster, } P \text {. nigra, } \\
\text { P. sylvestris }\end{array}$ & Spain & [139-141] \\
\hline $43-44$ & $\begin{array}{c}\text { Gremmeniella } \\
\text { abietina } \\
\text { mitochondrial RNA } \\
\text { virus S1, S2 } \\
\text { (GaMRV-S1, S2) }\end{array}$ & $\begin{array}{c}\text { Mtovirus, } \\
\text { Mitoviridae } \\
\text { (+)ssRNA }\end{array}$ & $\begin{array}{l}\text { Gremmeniella } \\
\text { abietina }\end{array}$ & $\begin{array}{l}\text { mainly Pinus } \\
\text { sylvestris, Picea, } \\
\text { Abies and Larix }\end{array}$ & $\begin{array}{c}\text { Northern and } \\
\text { Central Europe, } \\
\text { North America } \\
\text { and Japan, } \\
\text { Spain, Turkey }\end{array}$ & {$[142,143]$} \\
\hline 45 & $\begin{array}{l}\text { Gremmeniella } \\
\text { abietina RNA virus } \\
\text { L1 (GaRV-L1) }\end{array}$ & $\begin{array}{c}\text { Victorivirus, } \\
\text { Totiviridae } \\
\text { dsRNA }\end{array}$ & $\begin{array}{c}\text { Gremmeniella } \\
\text { abietina }\end{array}$ & $\begin{array}{l}\text { mainly Pinus } \\
\text { sylvestris, Abies } \\
\text { and Larix }\end{array}$ & Finland & [143] \\
\hline 46 & $\begin{array}{l}\text { Gremmeniella } \\
\text { abietina RNA virus } \\
\text { MS1 (GaRV-MS1) }\end{array}$ & $\begin{array}{c}\text { Gammapartitivirus, } \\
\text { Partitiviridae } \\
\text { dsRNA }\end{array}$ & $\begin{array}{l}\text { Gremmeniella } \\
\text { abietina }\end{array}$ & $\begin{array}{l}\text { Pinus sylvestris, } \\
\text { (Abies and Larix) }\end{array}$ & Finland & [143] \\
\hline 47 & $\begin{array}{c}\text { Gremmeniella } \\
\text { abietina RNA virus } \\
6(\mathrm{GaRV6})\end{array}$ & $\begin{array}{c}\text { Curvulaviridae } \\
\text { dsRNA }\end{array}$ & $\begin{array}{l}\text { Gremmeniella } \\
\text { abietina }\end{array}$ & Pinus halepensis & Spain & [144] \\
\hline 48 & $\begin{array}{l}\text { Gremmeniella } \\
\text { betaendornavirus } \\
(\mathrm{XL})(\mathrm{GBRV}-\mathrm{XL})\end{array}$ & $\begin{array}{l}\text { Endornaviridae } \\
\qquad(+) \text { ssRNA }\end{array}$ & $\begin{array}{l}\text { Gremmeniella } \\
\text { abietina }\end{array}$ & $\begin{array}{l}\text { Pinus sylvesris, } \\
\text { P. contorta }\end{array}$ & Finland & {$[145,146]$} \\
\hline 49 & $\begin{array}{l}\text { Gremmeniella } \\
\text { fusarivirus } 1 \\
\text { (GFV1) }\end{array}$ & $\begin{array}{l}\text { unclass. } \\
\text { Riboviria, } \\
\text { proposed } \\
\text { family } \\
\text { "Fusariviridae" } \\
\text { (+)ssRNA }\end{array}$ & $\begin{array}{l}\text { Gremmeniella } \\
\text { abietina }\end{array}$ & Pinus hapepensis & Spain & [146] \\
\hline $50-52$ & $\begin{array}{l}\text { Mycoreovirus 1, } 2 \\
3 \text { (MyRV-1-3) }\end{array}$ & $\begin{array}{l}\text { Mycoreovirus, } \\
\text { Reoviridae } \\
\text { dsRNA }\end{array}$ & $\begin{array}{l}\text { Cryphonectria } \\
\text { parasitica }\end{array}$ & $\begin{array}{c}\text { Castanea sativa, } \\
\text { Prunus }\end{array}$ & & [147-149] \\
\hline $53-60$ & $\begin{array}{c}\text { Ophiostoma } \\
\text { mitoviruses 1a, 1b, } \\
\text { 1c, 3a, 3b, 4, 5, } 6 \\
\text { (OMV1a-OMV6) }\end{array}$ & $\begin{array}{l}\text { Mitovirus, } \\
\text { Mitoviridae } \\
(+) \text { ssRNA }\end{array}$ & $\begin{array}{c}\text { Ophiostoma } \\
\text { novo-ulmi }\end{array}$ & Ulmus & UK, Canada & {$[150,151]$} \\
\hline $\begin{array}{c}61 \\
\text { HTS }\end{array}$ & $\begin{array}{c}\text { Phytophthora } \\
\text { alphaendornavirus } \\
1 \text { (PEV1) }\end{array}$ & $\begin{array}{c}\text { Alphaendornavirus, } \\
\text { Endornaviridae } \\
(+) \text { ssRNA }\end{array}$ & $\begin{array}{l}\text { Phytophthora } \\
\text { ramorum, } \\
\text { Phytophthora } \\
\text { taxon } \\
\text { douglasfir }\end{array}$ & $\begin{array}{c}\text { Pseudotsuga } \\
\text { menziesii, } \\
\text { Quercus agrifolia, } \\
\text { Viburnum spp., } \\
\text { Laurus nobilis, } \\
\text { Rhododendron }\end{array}$ & $\begin{array}{c}\text { USA, UK, } \\
\text { Netherlands }\end{array}$ & [152] \\
\hline $\begin{array}{c}62 \\
\text { HTS }\end{array}$ & $\begin{array}{l}\text { Phytophthora } \\
\text { cactorum RNA } \\
\text { virus } 1 \text { (PcRV1) }\end{array}$ & $\begin{array}{c}\text { unclass. } \\
\text { Totiviridae } \\
\text { dsRNA }\end{array}$ & $\begin{array}{l}\text { Phytophthora } \\
\text { cactorum }\end{array}$ & Betula pendula & Denmark & [153] \\
\hline $\begin{array}{c}63 \\
\text { HTS }\end{array}$ & $\begin{array}{c}\text { Sphaeropsis } \\
\text { sapinea RNA virus } \\
1 \text { (SsRV1) }\end{array}$ & $\begin{array}{l}\text { Victorivirus, } \\
\text { Totiviridae } \\
\text { dsRNA }\end{array}$ & $\begin{array}{l}\text { Diplodia pinea, } \\
\text { D. scrobiculata }\end{array}$ & Pinus roxburghii & South Africa & [154] \\
\hline
\end{tabular}

+ The virus distribution data were retrieved from the Invasive Species Compendium CABI in combination with information from the publications referred to in the present review. * Full-genome data for these viruses were generated by HTS (RNA-Seq or small RNA sequencing sRNA-Seq)) following their first discovery by traditional methods. 
Table 3. Mycoviruses occurring in mutualistic fungi and saprotrophs. For each virus, the virus name, genus and family name, fungal host(s), tree species, countries in which the virus was reported and the related references are given. Numbers in the first column represent ordinal numbers of the listed viruses. Viruses that were discovered by means of HTS methods are indicated by the note "HTS" next to their ordinal number.

\begin{tabular}{|c|c|c|c|c|c|c|}
\hline & Virus Name & $\begin{array}{l}\text { Genus, Family } \\
\text { Name }\end{array}$ & Fungal Host (s) & Tree Species & Distribution ${ }^{+}$ & References \\
\hline $\begin{array}{c}1 \\
\text { HTS }\end{array}$ & $\begin{array}{l}\text { Hygrophorus } \\
\text { penarioides } \\
\text { partitivirus } 1 \\
\text { (HpPV1) }\end{array}$ & $\begin{array}{c}\text { unclass. Alpha- } \\
\text { partitivirus, } \\
\text { Partitiviridae dsRNA }\end{array}$ & $\begin{array}{l}\text { Hygrophorus } \\
\text { penarioides }\end{array}$ & Quercus petraea & Turkey & [155] \\
\hline $\begin{array}{c}2 \\
\text { HTS }\end{array}$ & $\begin{array}{l}\text { Geopora } \\
\text { sumneriana } \\
\text { mitovirus } 1 \\
\text { (GsMV1) }\end{array}$ & $\begin{array}{l}\text { unclass. Mitovirus, } \\
\text { Mitoviri- } \\
\text { dae/Narnaviridae } \\
\text { (+)ssRNA }\end{array}$ & $\begin{array}{c}\text { Geopora } \\
\text { sumneriana }\end{array}$ & Cedrus libani & Turkey & [156] \\
\hline $\begin{array}{c}3 \\
\text { HTS }\end{array}$ & $\begin{array}{c}\text { Gyromitra } \\
\text { esculenta } \\
\text { endornavirus } 1 \\
(\text { GeEV1) }\end{array}$ & $\begin{array}{l}\text { unclass. } \\
\text { Endornaviridae } \\
(+) \text { ssRNA }\end{array}$ & $\begin{array}{l}\text { Gyromitra } \\
\text { esculenta }\end{array}$ & Pinus brutia & Turkey & [157] \\
\hline $\begin{array}{c}4 \\
\text { HTS }\end{array}$ & $\begin{array}{c}\text { Gyromitra } \\
\text { esculenta } \\
\text { partitivirus } 1 \\
\text { (GePV1) }\end{array}$ & $\begin{array}{c}\text { unclass. } \\
\text { Partitiviridae dsRNA }\end{array}$ & $\begin{array}{l}\text { Gyromitra } \\
\text { esculenta }\end{array}$ & Pinus brutia & Turkey & [158] \\
\hline 5 & $\begin{array}{l}\text { Lactarius rufus } \\
\text { RNA virus } 1 \\
\text { (LrRV1) }\end{array}$ & $\begin{array}{c}\text { Orthocurvulavirus, } \\
\text { Curvulaviridae } \\
\text { dsRNA }\end{array}$ & $\begin{array}{l}\text { Lactarius rufus, } \\
\quad \text { L. tabidus }\end{array}$ & $\begin{array}{l}\text { Pinus sylvesrtris, } \\
\text { Picea abies }\end{array}$ & Finland & [159] \\
\hline 6 & $\begin{array}{l}\text { Lactarius tabidus } \\
\text { RNA virus } 1 \\
\text { (LtRV1) }\end{array}$ & $\begin{array}{c}\text { Orthocurvulavirus, } \\
\text { Curvulaviridae } \\
\text { dsRNA }\end{array}$ & $\begin{array}{l}\text { Lactarius rufus, } \\
\quad \text { L. tabidus }\end{array}$ & $\begin{array}{l}\text { Pinus sylvesrtris, } \\
\text { Picea abies }\end{array}$ & Finland & [159] \\
\hline $\begin{array}{c}7 \\
\text { HTS }\end{array}$ & $\begin{array}{l}\text { Picoa juniperi } \\
\text { mycovirus } 1 \\
\text { (PjMTV1) }\end{array}$ & $\begin{array}{c}\text { unclass. Riboviria, } \\
\text { newly proposed } \\
\text { Megatotiviridae } \\
\text { dsRNA }\end{array}$ & Picoa juniperi & $\begin{array}{l}\text { various forest } \\
\text { tree species }\end{array}$ & Turkey & [160] \\
\hline 8 & $\begin{array}{l}\text { Tuber aestivum } \\
\text { virus } 1(\mathrm{TaV} 1)\end{array}$ & $\begin{array}{c}\text { Totivirus, Totiviridae } \\
\text { dsRNA }\end{array}$ & Tuber aestivum & $\begin{array}{l}\text { mixed beech } \\
\text { forest }\end{array}$ & Hungary & [161] \\
\hline 9 & $\begin{array}{c}\text { Tuber aestivum } \\
\text { endornavirus } \\
(\mathrm{TaEV})\end{array}$ & $\begin{array}{c}\text { Betaendornavirus, } \\
\text { Endornaviridae } \\
(+) \text { ssRNA }\end{array}$ & Tuber aestivum & $\begin{array}{l}\text { mixed oak } \\
\text { forest }\end{array}$ & Hungary & [162] \\
\hline 10 & $\begin{array}{l}\text { Tuber aestivum } \\
\text { mitovirus (TaMV) }\end{array}$ & $\begin{array}{c}\text { unclass. Mitovirus, } \\
\text { Mitoviridae }(+) \text { ssRNA }\end{array}$ & Tuber aestivum & $\begin{array}{l}\text { mixed oak } \\
\text { forest }\end{array}$ & Hungary & [163] \\
\hline 11 & $\begin{array}{l}\text { Tuber excavatum } \\
\text { mitovirus (TeMV) }\end{array}$ & $\begin{array}{c}\text { unclass. Mitovirus, } \\
\text { Mitoviridae ssRNA(+) }\end{array}$ & Tuber excavatum & $\begin{array}{l}\text { mixed beech } \\
\text { forest }\end{array}$ & Germany & [164] \\
\hline $\begin{array}{l}12-13 \\
\text { HTS }\end{array}$ & $\begin{array}{c}\text { putative alpha- and } \\
\text { betapartitiviruses } \\
(\mathrm{ScPV})\end{array}$ & Partitiviridae dsRNA & $\begin{array}{l}\text { Sarcosphaera } \\
\text { coronaria }\end{array}$ & Pinus brutia & Turkey & [165] \\
\hline
\end{tabular}

${ }^{+}$The virus distribution data were retrieved from the Invasive Species Compendium CABI in combination with information from the publications referred to in the present review.

\subsection{Plant Viruses Infecting Tree/Shrub Hosts and Cryptoviruses}

In the present review, we listed 43 plant viruses that affect 19 forest tree and shrub species present in the temperate forest and urban zone (Table 1 and references). The majority of these viruses are (+)ssRNA viruses of the families Betaflexiviridae (11 viruses), Secoviridae (seven viruses), Bromoviridae (five viruses), Tombusviridae (four viruses), Virgaviridae (three viruses) and Mayoviridae (one virus). Apart from the (+)ssRNA viruses, there is also a genus of (-)ssRNA, the Emaravirus, which is represented in the forest virome with four different species. There are also two reverse-transcribing dsDNA viruses: the birch leafroll-associated virus (BLRaV) in Betula spp. and the chestnut mosaic virus in Castanea sativa, both belonging to the Badnavirus genus (Family Caulimoviridae). Additionally, the first genetic evidence of the presence of another reverse-transcribing DNA virus has 
been reported in white ash (Fraxinus americana). Finally, three dsRNA viruses have been also detected in pines and in ash trees, two from the family Partitiviridae and one from Amalgaviridae.

In total, 21 viruses have been newly discovered within the last five years by applying HTS methodologies, which represent $49 \%$ of the total number of viral species in forest trees. Among these, three virus genera are overwhelmingly represented. These are the genus Emaravirus with four species to date (aspen mosaic-associated virus [42], common oak ringspot-associated virus [56,57], maple mottle-associated virus [74] and European mountain ash ringspot-associated virus [16]), the genus Badnavirus with two species (birch leafroll-associated virus [15] and chestnut mosaic virus [55]) and the genus Carlavirus with eight species (birch carlavirus [14], blueberry scorch virus [43,44], elderberry carlaviruses A, B, C, D, E [59,60] and elm carlavirus [61-63]). All the novel emara- and badnaviruses are found to be associated with the corresponding symptoms and are, consequently, plant pathogenic, while the role of carlaviruses is not yet clarified. Apart from these, single species are discovered from four other genera with (+)ssRNA: an Idaeovirus (unassigned species and family), a Capillovirus (Betaflexiviridae), a Bromovirus (Bromoviridae) and a Aureusvirus (Tombusviridae).

From the current knowledge, the majority of viruses detected in forest/shrub tree species exhibit a broad host range and were isolated in many other crops or trees (apple, cherry, tomato, tobacco, strawberry, blueberry, etc.) before their discovery in forest trees, but our aim is to reform this knowledge base, as there is a remarkably increasing number of novel viruses. The 21 novel viruses discovered through HTS to date are host specific and, following the nomenclature principles, the host name is included in the new species name. As a result, all novel virus species are named after their forest tree host. Only four viruses were named after a forest tree name before the discovery of the HTS: the poplar mosaic virus, the European mountain ash rinspot-associated virus, the elm mottle virus and the white ash mosaic virus.

\subsection{Mycoviruses Occurring in Plant Pathogenic Fungi}

In this study, we have summarized 63 viral species infecting ten highly important fungal or oomycete pathogens occurring in more than 11 genera of forest trees (Table 2 and references). In contrast to the plant pathogenic viruses, this group of viruses includes many dsRNA viruses mainly affiliated with the Partitiviridae family (17 viruses) but also families Totiviridae (three viruses) and Curvulaviridae (two viruses), while the family Reoviridae was represented by one virus species. As dsRNA viruses can be readily detected based on classical cellulose chromatography analysis, most of these viruses were already known before the employment of HTS methods. Similarly, some (+)ssRNA viruses, including members of Hypoviridae, Endornaviridae and Mitoviridae, had been already discovered prior to the HTS era based on their dsRNA replicative intermediates. HTS analysis has, however, revealed mitoviruses to be highly common in fungi, also in fungal species where members of this family were not earlier detected by classical virus screening methods. From the total of $33(+)$ ssRNA viruses detected, 23 belong to the family Mitoviridae; 11 novel mitoviruses have been detected during the last five years applying HTS, while Cryphonectria parasitica mitovirus 1 [126], Fusarium circinatum mitoviruses [139], Gremmeniella mitoviruses 1 and 2 [142,143], Hymenoscyphus fraxineus mitovirus 1 [138] and Ophiostoma mitoviruses $[150,151]$ were discovered earlier. Other $(+)$ ssRNA viruses revealed by HTS methodology include a virga-like virus (unclassified Virgaviridae) and an ourmia-like virus (family Botourmiaviridae) in Armillaria spp. [116]. HTS methodology has also allowed for the first time the detection of (-)ssRNA RNA viruses in our target pathogens: Armillaria mellea negative strand RNA virus 1 [116] and Cryphonectria parasitica sclerotimonavirus 1 [125] (both putative members of Mymonaviridae). Finally, new unclassified ambisense viruses were very recently identified and characterized: Cryphonectria parasitica ambivirus 1NB631 [125] and Armillaria ambi-like viruses [116]. Apart from the plant pathogenic fungi listed in Table 2, HTS has been shown to be a very efficient tool for the detection of viral 
diversity in the soilborne pathogen Rosellinia necatrix that infects many fruit trees and related natural trees, also leading to the discovery of members of Hypoviridae, as well as unclassified "fusagraviruses" and "megatotiviruses" [166]. Similarly, unclassified (+)ssRNA viruses of the proposed family "Fusariviridae" (proposal submitted to ICTV in June 2021) were discovered for the first time in Gremmeniella abietina by HTS [146].

The vast majority of fungal viruses are transmitted intracellularly, which enables them to spread without movement proteins and even without being protected by protein capsids. Due to this close host association and long co-evolution, most mycoviruses do not cause a major host debilitation. However, as described in more detail in the discussion below, there are several important exceptions where mycoviruses reduce the virulence or growth rate of their host and hence improve the health of the holobiont. The most important example is the chestnut blight pathogen, Cryphonecria parasitica, which can be controlled via the introduction of hypoviruses $[167,168]$, while two alphapartitiviruses of Heterobasidion spp. [169] and a mycoreovirus of Rosellinia necatrix have also shown promising results $[170,171]$ (see discussion). However, the outcome of a mycovirus-host association is complex and may be dependent on environmental conditions, interacting fungi or coinfecting viruses $[130,147,169]$.

\subsection{Mycoviruses Occurring in Mutualistic Fungi and Saprotrophs}

In Table 3, we have summarized 13 viral species infecting eleven species of ectomycorrhizal (ECM) fungi associated with both broadleaved and conifer trees. Again, dsRNA viruses predominate; most of them belong to the family Partitiviridae (four viruses) and the rest to the families Curvulaviridae (two viruses) and Totiviridae (one virus). Thanks to HTS, novel dsRNA viruses were detected for first time in several species of ECM fungi in Turkey: Picoa juniperi (dsRNA virus of the proposed family Megatotiviridae, [160]), Sarcosphaera coronaria (putative Partitiviridae member, [165]), Hygrophorus penarioides (partitivirus, [155]), and in the false morel mushroom Gyromitra esculenta [158]. Regarding ssRNA(+) viruses, they had already been identified with traditional methods, including putative members of Mitoviridae (three viruses) and Endornaviridae (two viruses). For the first time, a mitovirus was, by means of HTS, fully genetically characterized in the ectomycorrhizal fungus Geopora sumneriana [156].

The first viruses infecting ECM fungi were discovered in commercially valuable truffles (genus Tuber), and only recently, viral diversity in mycorrhizal fungi has been addressed more from an ecological viewpoint. While HTS studies have already revealed hitherto unknown evolutionary trajectories and new viral genome organizations in ECM fungi and other mycorrhizae [172], the phenotypic effects of most of these viruses have not been systematically studied.

Saprotrophs that consume coarse or fine woody debris are somewhat less intimately connected with the plant host than mycorrhizal fungi and pathogens, and most of them cannot be connected to a single genus of host trees. Some of them produce edible fruiting bodies and for this reason have been subjected to virus screening studies by HTS. The shiitake mushroom (Lentinula edodes) is found on many broadleaved tree species, and although virus-like particles were found in this species already in the 1970s, HTS has recently revealed many new virus taxa, most notably, (-)ssRNA viruses not detected by traditional methods $[173,174]$. Very recently, a novel $(-)$ ssRNA virus of the family Mymonaviridae and a partitivirus were also identified with the use of RNA-Seq in the Bondarzewia berkeleyi from oak wood [175]. Other important wood decay fungi known to be infected by symptomatic viruses but not yet subjected to HTS include, for example, the enokitake (Flammulina velutipes) [176] and the oyster mushroom (Pleurotus ostreatus) [177], favouring broadleaved trees.

\section{Virome of Specific Plant Hosts}

3.1. Acer spp.

Arabis mosaic virus, cucumber mosaic virus, maple mottle-mssociated virus 
Maples are abundantly found in temperate forests and urban parks, with the most common species, A. pseudoplatanus (sycamore) and A. platanoides (Norway maple), representing a natural component of birch (Betula spp.) and fir (Abies spp.) forests [178]. With a natural distribution across the globe, maples occur in many habitats from the high altitudes of the Himalayas, to the rainforests of South East Asia, to rocky cliffs in the Mediterranean and the edge of swamps in N. America. In addition to the horticultural uses and the tourism related value of maples, they are also of importance to the timber industry and valuable as a food. A number of the larger maples are commercially grown for timber in N. America and Europe: A. saccharum, A. nigrum, A. negundo, A. rubrum, A. pseudoplatanus. Maple sugar and maple syrup can be primarily produced from sugar maple (A. saccharum), black maple (A. nigrum) and manitoba maple (A. negundo) [179]. As with many other tree species, maples are under threat in the wild primarily as a result of forest degradation and destruction. Global climate change adds further pressure to those maples that are naturally rare or restricted to high elevations. Out of a total of 191 maples assessed by the IUCN/SSC Global Tree Specialist Group, 83 are considered threatened with extinction at the global scale and therefore require conservation action [178].

Viral diseases in different maple species have since long been reported [180,181]. Arabis mosaic virus [40,41] has been reported to infect Acer spp. However, until recently, maple has never been unambiguously described as a host for any well-characterized viral agent. Employing HTS methodology, a novel emaravirus was recently reported in sycamore maple (A. pseudoplatanus) exhibiting leaf mottle symptoms in Germany and was genetically characterized [74]. RNA-Seq was performed on the Illumina HiSeq2500 system using RNA preparations from symptomatic and symptomless maple trees. The sequence assembly and analysis revealed the presence of six genomic RNA segments in the symptomatic sample; RNA1 encoding the viral replicase (RdRP), RNA2 encoding the glycoprotein precursor (GPP), RNA3 encoding the nucleocapsid protein (N), RNA4 encoding the putative movement protein (MP) and RNA5 and RNA6 encoding proteins of unknown function. The novel virus was named maple mottle-associated virus (MaMaV), and evidence is provided that it may be the symptom-inducing virus in the diseased trees. The maple virome of the symptomatic tree tested was found to be very simple, as it included a single variant from a single virus. The lack of virome complexity is rather surprising, when we consider the HTS results obtained from other wild as well as cultivated woody hosts. A possible explanation could be the age of the tree; it was 3 years old when it was sampled, thus it was exposed for only a short time to viral pathogens [74].

\subsection{Betula spp.}

apple mosaic virus; arabis mosaic virus; birch leafroll-associated virus; birch capillovirus; birch carlavirus; birch idaeovirus; cherry leaf roll virus; Phytophthora cactorum RNA virus 1 ; tobacco necrosis virus; tomato ringspot virus

Birches are an essential ecological component in northern temperate and boreal forests [182]. They are light-demanding early successional pioneer species, which rapidly occupy open areas after forest fires and clear-cuttings due to their prolific seed production and fast juvenile growth [183]. For forestry, birch is the most important broadleaved tree species in northern and eastern Europe. In Nordic countries, the proportion of birch out of the total volume of the growing stock varies between 11 and 16\% and in Baltic countries, 17 and $28 \%$ [184]. Its ecological impact is unique, as it constitutes part of the few remaining old-growth forests growing in Europe, the proportion of which is rapidly decreasing across the entire boreal zone. Additionally, it contributes to forest resilience and the rapid restoration of wood production after disturbance by colonizing forest gaps and quickly increasing soil functioning and biodiversity [183]. Regarding biodiversity, the number of specialized flora and fauna species associated with birch is higher than for other tree species in Europe, particularly for mycorrhiza and insects. Furthermore, birch is adaptable to diverse climate conditions and can be integrated in diverse productive mixed tree stands, 
being, therefore, an appropriate forest species under current circumstances of rapid climate change. Concretely, regarding B. pedula and B. pubescens, due to the numerous strengths and potentials of these tree species, it is recommended by Dubois et al. [184] to expand its use in the Western European forestry considering societal, ecological, and economic purposes in a changing climatic and socio-economic context.

Several common tree viruses have been since long reported in birch: apple mosaic virus [31,34], arabis mosaic virus [35], cherry leaf roll virus [46], tobacco necrosis virus [35] and tomato ringspot virus [35]. In Finland, a severe birch decline was first observed in 2002 involving leaf symptoms such as vein banding, leaf roll, chlorosis and subsequent necrosis, causing a loss of vigor and degeneration in the trees. The disease has been widely distributed the last two decades, so far being reported in five European countries with diverse climate conditions (Finland, Sweden, Norway, Germany and France) [13,185-188]. The emerging phenomenon was described as "birch leaf-roll disease" (BLRD) [12,187] and was initially related to the presence of cherry leaf roll virus (CLRV) in the affected treesbased on standard molecular diagnostic tools $[12,13,188]$. However, the employment of HTS radically changed our concept regarding the causal agent of the BLRD. RNA-Seq revealed the presence of a novel badnavirus in affected birches [15], while a complex virome involving novel and known viruses was revealed; apart from the novel badnavirus, birch leafroll-associated virus (BLRaV), also birch idaeovirus, birch capillovirus, birch carlavirus and cherry leaf roll virus were present in symptomatic trees [14]. Interestingly, in single hosts, the virome could be highly variable, with up to five viruses and different variants of BLRaV and CLRV being detected in one sample. Based on the metagenomic analysis of three birches that exhibited symptoms and two that did not exhibit symptoms and on further analyzing a considerable number of samples [189], it is suggested that BLRaV is the main causal agent of BLRD; however, the other viruses could possibly still contribute to symptom development in cases of mixed infection with BLRaV and/or CLRV.

The oomycete Phytophthora cactorum is a birch pathogen that causes stem lesions and infects mostly nursery seedlings [190]. Besides birch, it infects over 200 species of trees, ornamentals and fruit crops. A recent HTS study revealed alphaendornaviruses, bunya-like viruses, a toti-like virus and viruses affiliated to the unclassified dsRNA virus group tentatively called "ustiviruses" in P. cactorum isolated from strawberry plants [153]. Furthermore, birch may be infected with Armillaria root rot fungi, which typically attack trees weakened by drought or other pathogens. A recent NGS study detected a novel virus group called "ambiviruses" in Armillaria borealis growing on birch wood [116].

\subsection{Castanea Sativa}

chestnut mosaic virus, Cryphonectria hypovirus 1, mycoreovirus 1

The sweet chestnut (Castanea sativa) is the only native species of the genus in Europe [191]. The broad diffusion and active management by man resulted in the establishment of the species at the limits of its potential ecological range. The present distribution ranges from North-Western Africa (e.g., Morocco) to North-Western Europe (southern England, Belgium) and from south-western Asia (e.g., Turkey) to Eastern Europe (e.g., Romania), the Caucasus (Georgia, Armenia) and the Caspian Sea. The sweet chestnut has a remarkable multipurpose character and may be managed for timber production (coppice and high forest) as well as for fruit production (traditional orchards), including a broad range of secondary products and ecosystem services [191].

Chestnut mosaic disease (ChMD) represents one more case in the forest pathology, where knowledge concerning the causal agent was gained thanks to HTS and bioinformatics analysis. The disease was described several decades ago in Italy [192] associated with viral symptoms, such as mosaic and shoots with asymmetric leaf blade deformation. In 1987, it was reported in France [193], involving necrotic lesions in the bark and wood that turn into cankers, chlorotic lesions and yellow stripes on leaf veins and partial limb atrophy, thus heavily affecting the production [194]. By using RNA-Seq analysis, two independent 
isolates of the same novel virus were identified [55]. The novel chestnut mosaic virus belongs to the genus Badnavirus, family Caulimoviridae; it is unambiguously proven to be episomal and is strongly suggested to play causal role in the disease development.

Chestnut blight is another serious disease of chestnut caused by the ascomycete Cryphonectria parasitica. As stated above, hypoviruses infecting the pathogen have been successfully used to control the fungus, and the subsequent natural spread of these viruses has protected European chestnut trees from complete devastation [167,168]. Additionally, other viruses (including Mycoreovirus 1 and Cryphonectria mitovirus 1) infect this pathogen, and these have been recently examined for their biocontrol and transmission potential in planta. Some promise was shown, but the use of the viruses is highly dependent on their transmission efficacy [195].

\subsection{Fraxinus spp.}

arabis mosaic virus; cherry leaf roll virus; Hymenoscyphus fraxineus mitovirus 1; tobacco mocaic virus; tobacco necrosis virus; tobacco ringspot virus; white ash mosaic vi-rus; putative cryptovirus; putative caulimovirus

Although several viruses are reported in ash trees, all of them are generalists, and none of them is host specific. The most common are arabis mosaic virus [37,38], cherry leaf roll virus [47], tobacco necrosis virus [105], tobacco mosaic virus [97-99], tobacco ringspot virus [98,99,110], tomato ringspot virus [96] and white ash mosaic virus [114].

With the use of HTS, a novel putative partitivirus and a novel putative caulimovirus have been identified in Fraxinus americana [115], exhibiting symptoms distinct from those caused by previously reported ones, namely, chlorotic patches and necrotic lesions on leaves. Commonly, members of Partitiviridae are not pathogenic for their host; recently, however, new members of the family were found to be associated with symptom development. Nevertheless, further studies are needed in order to fully characterize the new viruses in ash.

A recently discovered mycovirus related to the ash microbiome/virome is Hymenoscyphus fraxineus mitovirus 1 (HfMV1) [138]. H. fraxineus is a pathogen recently introduced into Europe from Asia, causing ash dieback and threatening ash stands all across the continent [196]. H. fraxineus isolates from Europe were previously shown to harbor HfMV1, while later, a viral population with higher genetic diversity was detected in $H$. albidus, a harmless litter saprotroph native in Europe. This fact suggests multiple interspecific virus transfers from $H$. albidus to $H$. fraxineus [196].

\subsection{Picea spp.}

Heterobasidion mitovirus 1, 2 and 3; Heterobasidion RNA virus 6; Heterobasidion partitiviruses; Picea mariana tenuivirus; tomato mosaic virus; tomato mosaic virus

Concerning Norway spruce, it is a long-living species ( $>200$ years-old) with a long tradition of cultivation for its straight trunk, particularly used for timber constructions, pulpwood for paper and furniture [197]. Its high economic and ecological significance calls for taking proactive measures against potential viral emergence. Starting from the 1980s, spruce forests have shown symptoms of decline in mountainous areas of central Europe, including yellowing, loss of needles, die-back of branches and reduced growth. Due to widespread spruce pathogens and pests, such as Heterobasidion parviporum and Ips typographus, as well as health problems of unidentified aetiology, its popularity for reforestation, particularly outside its natural range in central European forests, has been reduced, although it remains the most commercially valuable tree species in the Nordic countries.

From the plant pathogenic viruses, only tomato mosaic virus has been reported in spruce $[93,94]$. Picea mariana has been reported to host (-)ssRNA viruses of the genus Tenuivirus [198]. 
The most important fungal pathogen infecting Norway spruce is Heterobasidion parviporum, which causes economic losses of hundreds of millions of euros annually in Europe [199]. Like the related species, H. annosum prefers pines as its host, and H. parviporum hosts partiti-, curvula- and mitoviruses (Table 2). The Heterobasidion partitivirus 15 (HetPV15-pa1) of H. parviporum is associated with the debilitation of its fungal host [169]. The ectomycorrhizal symbionts of spruce include species of Lactarius, L. tabidus being one of the most common ones. This species also harbors members of the family Curvulaviridae (Table 3; [159]).

\subsection{Pinus spp.}

Gremmeniella abietina RNA virus MS1; Gremmeniella abietina RNA virus L1; Gremmeniella abietina mitochondrial RNA virus S1 and S2; Fusarium circinatum mi-tovirus 1, 2-1 and 2-2; Heterobasidion partitiviruses; Pinus nigra virus 1; Pinus patula amalgavirus 1; Pinus sylvestris partitivirus NL-2005; Sphaeropsis sapinea RNA virus 1; tobacco necrosis virus

Pinus spp. are attacked by various fungal pathogens, including the root rot fungi Heterobasidion annosum (Europe) and H. irregulare (North America and Europe as an introduced invasive species). These pine pathogens host viruses of the families Partitiviridae and Mitoviridae, and both virus families also have apparently cryptic members infecting plants ([137]; https: / / talk.ictvonline.org/, accessed on 26 July2021). The Heterobasidion partitivirus 13 (HetPV13-an1) of H. annosum is associated with host debilitation ([200]; see Discussion). H. annosum also hosts Heterobasidion RNA virus 6 (HetRV6), a member of a newly classified family, Curvulaviridae (Table 2; [129]). The spore-mediated dispersal of $H$. annosum and H. parviporum can be controlled by the preparation of the saprotroph Phlebiopsis gigantea, which acts as an antagonist to Heterobasidion spp. and occurs very commonly in newly cut conifer wood, especially Scots pine. P. gigantea can be infected by mycoviruses tentatively named "phlegiviruses" according to their host fungus [201].

Pines also suffer from needle diseases, such as Scleroderris cancer caused by Gremmeniella abietina and wilting disease caused by the globally spreading pathogen Fusarium circinatum. The ascomycete G. abietina causes shoot blight and stem canker of several conifers in Europe and N. America. The fungus hosts a diverse virus community (Table 2; [146]). One of the viruses, representing the virus family Curvulaviridae, has been associated with phenotypical changes in the host (enhanced mycelial growth) [144]. F. circinatum is also commonly infected with mitoviruses (Table 2, [139-141]). Viruses of the families Totiviridae and Mitoviridae also occur in the pine needle pathogens Diplodia pinea and Cronartium ribicola, respectively (Table 2 ).

On the other hand, pines have several fungi as their symbiotic partners form ectomycorrhizal associations. One of the most common is Thelephora terrestris, which hosts a "phlegivirus" that was also detected in soil oribatid mites, suggesting that even some RNA mycoviruses could have arthropod vectors [202]. Additionally, the basidiomycete Lactarius rufus is a highly common ectomycorrhizal symbiont of pine trees and has been shown to be commonly infected by members of the family Curvulaviridae (Table 3; [159]). Remarkably, a single ascocarp of the ectomycorrhizal crown cup fungus Sarcosphaera coronaria associated with Pinus brutia was shown to be infected with $\sim 34$ different partitiviruses [165]. The same research group found a partitivirus in another ectomycorrhizal partner of P. brutia, Gyromitra esculenta [158], which may also be infected by endornaviruses as revealed by the in silico analysis of transcriptomic datasets [157].

Not many plant pathogenic viruses from the Pinus trees themselves are known. One of the rare ones is the cryptovirus Pinus sylvestris partitivirus NL-2005 (Table 1, [81]). Additionally, Pinus patula amalgavirus 1 has been reported in a transcriptome shotgun assembly (TSA) database [80], illustrating the value of mining the TSA and other databases for novel viral sequences. 
Pinus nigra virus 1, an unclassified Caulimoviridae member, was discovered through air metagenomics (using Illumina technology) in Spain and was later PCR-detected in Pinus nigra samples from the vicinity of where the air samples were collected. This suggests that this new virus is likely a pathogen of Pinus [79]. Another pathogenic virus reported in Pinus is tobacco necrosis virus [106], but it has not been further investigated.

\subsection{Populus spp.}

arabis mosaic virus; Armillaria borealis mycovirgavirus 1; Armillaria borealis am-bilike virus 1 and 2; aspen mosaic-associated virus; poplar mosaic virus; tobacco necrosis vi-rus; tomato black ring virus

Populus is a tree native to most of the Northern Hemisphere including 25-30 species. Six of these aspen species play a disproportionately important role in promoting biodiversity, sequestering carbon, limiting forest disturbances and providing other ecosystem services [203]. Importantly, aspen species are commonly designated "keystone species", meaning their sustained existence supports an inordinate number of dependent plants and animals.

Regarding viruses affecting poplars, four viruses have been previously identified: arabis mosaic virus [36], tomato black ring virus [36], tobacco necrosis virus [106] and poplar mosaic virus [82-84]. The latter is one of the few viruses discovered in the beforeHTS-era that is a specialist. Very recently, based on RNA-Seq analysis, a novel emaravirus was discovered in Eurasian aspen, named aspen mosaic-associated virus [42]. The monocistronic, segmented ssRNA genome of the virus shows a genome organization typical for emaraviruses encoding the viral RdRP on RNA1, a GPP on RNA2, the viral N on RNA3 and a putative MP on RNA4. The fifth identified genome segment (P28) encodes a protein of unknown function. The virus is closely associated with observed leaf symptoms, such as mottle, yellow blotching, variegation and chloroses along veins. Observed symptoms and testing of mosaic-diseased Eurasian aspen by RT-PCR confirmed a wide geographic distribution of the virus in Fennoscandia [42].

Poplars, as many other hardwood trees, are also readily infected by species of Armillaria. One of the most common species is A. borealis occurring in both conifers and hardwoods. Recently, HTS analysis revealed a Siberian isolate of $A$. borealis from Populus spp. to be infected by multiple viruses, including a novel ssRNA(+) virus named Armillaria borealis mycovirgavirus 1 and three ambi-like viruses [116].

\subsection{Quercus spp.}

Armillaria mellea negative strand RNA virus 1; Armillaria mellea ourmia-like virus 2; common oak ringspot-associated virus; tobacco mocaic virus; tobacco necrosis virus

The genus Quercus contains over 500 species. Oaks are amongst the most economically and ecologically important deciduous trees in Europe providing wood for fuel, bark for tanning, timber for construction and acorns for livestock [204]. Here, we present existing virome data from Q. robur (common oak), Q. petraea, Q. variabilis (chinese oak), and Q. rubra that are native in Europe, North America and Asia.

Apart from two viruses with wide host spectra reported to occur in oaks, tobacco necrosis virus [106] and tobacco mosaic virus [97-104], still the main virus disease affecting the species remained unidentified until recently. The "chlorotic ringspot" disease of oaks originating from the USA was reported in the 1970s in Europe [104], and its occurrence was estimated to be relatively high in Germany and Scandinavia [6]. The disease was also found to affect $11-19 \%$ of oak seedlings in propagation stations, threatening by wider spread of the disease through the infected oak propagation material [6]. Due to the employment of HTS strategies, the causal agent of the disease was recently identified; the common oak ringspot-associated virus $(\mathrm{CORaV})[56,57]$ represents a new member of the genus Emaravirus comprising five RNA segments. Typically for emaraviruses, the RdRP is encoded by RNA 1, while RNA 2 encodes the GPP. The viral nucleocapsid protein (N) 
is encoded by RNA 3, and RNA 4 encodes the MP. RNA 5 of CORaV contains one major open reading frame, coding for a protein P5 of 179 aa; however, the function of P5 remains to be elucidated. This is one more occasion where metagenomic analysis provided the diagnostic answer to a problem that has remained unsolved for a long time.

Apart from the virus diseases, oaks also suffer from the "Sudden Oak Death" caused by Phytophthora ramorum - an oomycete that can kill oaks within a few weeks-and from "Oak Wilt" - caused by the fungus Ceratocystis fagacearum. The oak forest decline is a serious problem in North and South America. In the USA, entire oak ecosystems have declined due to a combination of factors that remain unclear [205]; it is, however, hypothesized that viral diseases are part of this complex syndrome. Notably, endornavirus strains have been found in Phytophthora ramorum isolates from various host plants, including Rhododendron and Viburnum species, both in the United States and Europe, but unfortunately, they do not seem to cause host debilitation that could be used for disease mitigation [152]. Already declining oak trees also readily suffer from infections by Armillaria root rot fungi. Recent discoveries of viruses in Armillaria spp. [116] also prompt the search of debilitation-associated viruses in these species. However, the viruses found thus far (Armillaria mellea negative strand RNA virus 1 and Armillaria mellea ourmia-like virus 2) in A. mellea from oak trees in South Africa did not seem to reduce the growth of their host in laboratory conditions.

Oaks are known to form mycorrhizal associations with both ascomycetes, such as true truffles (Tuber spp.) and Cenococcum geophilus, as well as basidiomycetes, such as species of Lactarius, Russula and Cortinarius. Viruses have been found in the ectomycorrhizal fungus Hygrophorus penarioides, but their possible effects on the tree-fungus association are unknown to date [155]. Moreover, Tuber spp. (T. excavatum and T. aestivum) have been shown to harbor diverse viruses of the families Totiviridae, Endornaviridae and Mitoviridae (Table 2).

\subsection{Sambucus spp.}

blueberry scorch virus; cherry leaf roll virus; cherry rasp leaf virus; elderberry aureusvirus 1; elderberry carlavirus A, B, C, D and E; elderberry latent virus; Sambucus virus $\mathrm{S}$; tobacco ringspot virus; tomato bushy stunt virus; tomato black ring virus

Elderberry (Sambucus nigra L.) is a deciduous tree native to Europe and North America. Its flowers and berries are used to prepare infusions, syrups and jellies and in traditional medicine. The popularity of this plant has increased in recent years in the pharmaceutical and food industries, due to its antiseptic and antiviral properties as well as to the interest in the colour compounds present in the berries [206].

From the abundant viruses affecting elderberry, eight are generalists and seven are specialists. Blueberry scorch virus [44], cherry leaf roll virus [49], cherry rasp leaf virus [54], tomato bushy stunt virus [50,91], tomato black ring virus [90] and tobacco ringspot virus [112] have been reported for a long time in elderberries and in other forest species worldwide. One of the specialists in this host is elderberry latent virus $[49,59]$ reported in the USA. HTS technology contributed to our knowledge on viral diseases in elderberry with the discovery of seven host specific viruses. The elderberry aureusvirus 1 is either asymptomatic or associated with mild chlorotic mosaics and was detected by applying Illumina sequencing in dsRNAs [58]. Through dsRNAs Illumina sequencing the bromovirus sambucus virus $S$ was also identified [85]. Five elderberry carlaviruses (elderberry virus A-E) were detected with the use of a degenerate oligonucleotide primed (DOP) RT-PCR method with multiple barcodes for HTS, involving VirFind, a novel and automated bioinformatics tool specifically used for virus detection and discovery $[59,60]$.

\subsection{Sorbus spp.}

apple chlorotic leaf spot virus; apple mosaic virus; cherry leaf roll virus; European mountain ash ringspot-associated virus 
The mountain-ashes are native throughout the cool temperate regions of the Northern Hemisphere, with the highest species diversity in the Himalaya. S. aucuparia, commonly called rowan, is an important deciduous tree or shrub, native to most of Europe and parts of Asia, as well as northern Africa. It serves as an ornamental urban species; it is also cultivated for its fruits and its timber [207].

The main disease affecting $S$. aucuparia is the "European mountain ash ringspot disease" caused by European mountain ash ringspot-associated virus (EMARaV), inducing chlorotic ringspots, mottle and line pattern on leaves and is widespread in central/northern Europe and England [16]. In addition to symptom development, EMARaV also causes symptomless infections; it is, therefore, assumed to be more common in the wild mountain ash trees than previously thought. Monitoring EMARaV in European forests revealed a very important aspect in viral epidemiology: the ability of viral pathogens to have an extended host range. Concretely, EMARaV was recently detected in new hosts, namely, in Amelanchier spp. in Germany [20], Karpatiosorbus $x$ hybrid in Finland [18] and Sorbus intermedia in Sweden [19]. Concretely, in S. intermedia (Swedish whitebeam), it was revealed through high-throughput Illumina RNASeq that EMARaV in this host possesses two additional RNA segments, in contrast to the four RNAs known to be possessed by EMARaV in mountain ash [19]. The fifth genome segment identified in diseased whitebeam codes for a protein showing distant aa sequence identity to the functionally characterized MPs encoded by other putative MPs of similar size encoded by the RNA4 of other emaraviruses. This suggests that it is the functional orthologue responsible for cell-to-cell transport of the virus. The two additional genome segments were consistently detected in affected Swedish whitebeam as well as in diseased S. aucuparia, together with the previously known RNA1RNA4 segments. The systematic presence of RNAs 5 and 6 in diseased Sorbus spp. and their absence in healthy trees suggest that the two newly identified genome segments encode proteins that are indispensable for the virus. Future studies are required to functionally confirm that the RNA5-encoded protein is the EMARaV MP and to investigate the role of the P27 encoded by the novel RNA6 in the life cycle of EMARaV.

Apart from EMARaV, only a few viruses have been detected in mountain ash: the apple mosaic virus [31], the apple chlorotic leaf spot virus [29] and the cherry leaf roll virus [51].

\subsection{Ulmus spp.}

cherry leaf roll virus; elm carlavirus; elm mottle virus; tomato ringspot virus; Ophiostoma mitoviruses

Several viruses have been reported to affect elms: elm mottle virus [64,65], tomato ringspot virus [95] and cherry leaf roll virus [51,208]. Recently, a disease affecting elms attributed to a non-characterized virus was investigated with the use of RNA-Seq methodology. This method revealed the presence of a novel carlavirus, the elm carlavirus [61-63], which is strongly suggested to be the causal agent of dieback and leaf symptoms, such as chlorotic ringspots, mottling and necroses in elms.

Mitoviruses are common in Ophiostoma ulmi and O. novo-ulmi, the causal agents of the Dutch elm disease (DED), devastating American elms but also causing epidemics in Europe and North America after new introductions. Some of these mitoviruses are associated with the reduced growth and sporulation of the host fungus [209]. Eight independently replicating mitoviruses were detected by Doherty et al. [150] in one diseased isolate of O. novo-ulmi, while two more mitoviruses were detected in a Canadian isolate of O. novoulmi [151]. The use of virus-induced hypovirulence as a biological control relies on the ability to transfer the virus between isolates within a population of the target pathogen. RNA viruses that have been found in 0 . novo-ulmi to date are located in mitochondria and can only be transmitted during anastomosis between compatible hyphae or induced forms of cytoplasmic mixing [151]. These findings raise the potential for engineering these 
viruses to include other genetic elements, such as anti-sense or interfering RNAs, to create novel and highly specific biological controls.

\subsection{Other Tree Species}

1. Prunus spp.: Prunus trees may suffer from infections by Chondrostereum purpureum, which causes silver leaf disease and has been developed as a biocontrol tool for the prevention of sprouting. The fungus hosts an alphapartitivirus called Chondrostereum cryptic virus 1 [210]. This tree genus may also be attacked by the notorious white root rot fungus Rosellinia necatrix that has a very broad host range, including both tropical and temperate fruit and forest trees.

2. Aesculus spp.: Some plant pathogenic viruses have been reported in Aesculus (apple chlorotic leaf spot virus, apple mosaic virus, cherry leaf roll virus and strawberry latent ringspot virus) (Table 1). Cryphonectria hypovirus 1 , most commonly affecting Cryphonectria parasitica in chestnut, is also present in Aesculus hippocastanum (Table 2).

3. Fagus spp.: Earlier reports exist on the occurrence of cherry leaf roll virus and tobacco necrosis virus in beech. A recent RNA-Seq investigation revealed a novel carlavirus related to leaf symptoms in trees in Germany [62].

4. Robinia spp.: Strawberry latent ringspot virus and peanut stunt virus (Iran) (Table 1) have been reported.

5. Salix spp.: A few generalist viruses may occur in Salix, such as brome mosaic virus, tomato mosaic virus and tobacco necrosis virus.

6. Cedrus libani: The ectomycorrhizal ascomycete Geopora sumneriana is associated with Lebanon cedar. Recently, Geopora sumneriana mitovirus 1 was identified in this fungal species [156].

7. Abies spp.: No plant pathogen has been reported. Several partitivirus have been reported in Heterobasidion basidiomycetes infecting diverse Abies species: Heterobasidion partitivirus 1 in A. cephalonica; Heterobasidion partitivirus 10 in A. concolor; and Heterobasidion RNA virus 6 (an orthocurvulavirus) in A. alba, A. sibirica, A. cephalonica, A. cilicica, A. equi-trojani and A. concolor (Table 2).

8. Pseudotsuga menziesii: Aphaendornaviruses infect members of Phytophthora ramorum and Phytophthora taxon douglasfir [152].

\section{Discussion}

Based on the data presented in the current review, it has become obvious that HTS has considerably impacted discovery of novel viruses in organisms (trees and fungi) that contribute to what a forest is. Analogically, our knowledge regarding virus communities in urban parks has considerably increased. Almost half of the plant pathogenic viruses and cryptoviruses in plants ( 21 out of 43 ), $35 \%$ of the mycoviruses infecting pathogenic fungi (22 out of 63 ) and $54 \%$ of the mycoviruses occurring in non-pathogenic fungi (7 out of 13) were discovered due to the employment of HTS strategies. Specifically considering phytopathogenic viruses, novel viruses were not identified in random environmental or host samplings, but after targeting diseased trees, where the disease has been previously identified and the disease distribution was monitored for a long time period; however, the causal agent had not been identified due to limitations in the existing conventional molecular diagnostic methods. Concerning mycoviruses, even in species that have previously been extensively investigated, the HTS of a small number of isolates has revealed novel $(+)$ ssRNA and (-)ssRNA viruses, which were viruses undetectable by traditional methods. The ability of HTS methods to extend the genetic investigation to a depth that had not been earlier achieved has resulted in extraordinary discoveries that have radically changed the view of forest pathology.

The vast majority of the viral families described in land plants are also shown to be present in the forest virome. Only viruses belonging to the realm Monodnaviria are not found in the forest, neither in tree nor in fungal hosts. Similarly to the taxonomical content of viruses described in plants, from the kingdom Orthornavirae, the (+)ssRNA viruses 
dominate the forest virome (members from seven families detected). Additionally, from the Orthornavirae, one virus genus of (-)ssRNA viruses, which are scarce in plants, the Emaravirus (Fimoviridae), and two families of dsRNA viruses (Partitiviridae and Amalgaviridae) were found, and this was achieved via HTS technologies. From the Pararnavira kingdom, only the family Caulimoviridae is represented with several RT viruses in the plant section of the forest virome. These are novel pathogenic viruses in birch, chestnut, pine and ash, which were unsuccessfully investigated with conventional diagnostic methods for many years, until HTS finally provided the solution. Concerning mycoviruses, analogously to land plants, dsRNA viruses also predominate in the forest, while RT viruses and circular ssDNA viruses have not yet been detected. By employing HTS, numerous novel dsRNA viruses, members of the families Partitiviridae, Totiviridae, Megatotiviridae (newly proposed family; [160]) and Megabirnaviridae (10 ${ }^{\text {th }}$ report of ICTV; [211]) were characterized. The list of $(+)$ ssRNA viruses was further extended with the recent HTS-generated data. It needs to be underlined that, according to ICTV, Endornaviridae is no longer a dsRNA, as previously described [4], but rather a family of (+)ssRNA viruses [212]. Apart from Endorna-, the families Virga-, Botourmia, Mito- and Fusariviridae are also newly represented in the forest mycovirome thanks to the discoveries of HTS. Furthermore, for the first time, (-)ssRNA viruses were detected in the fungal section of the forest virome: two of them belong to the family Mymonaviridae [213] and one belongs to the unclassified virus genus Ambivirus [125].

The massive discoveries of viruses in the forest ecosystem based on HTS technologies usually only refer to the full or partial genome sequence of the novel viruses, while knowledge on its biology and symptom expression is limited. To provide a basis for assessing the risk the novel viruses pose and make scientifically based decisions, a series of unavoidable steps need to be taken [214]. The early steps include the confirmation of infection using complementary methods; provisional taxonomy assignment; sample documentation adding information such as symptomatology and geographical origin; full genome sequencing and annotation (in cases of incomplete viral sequences); and the development of a diagnostic protocol accessible to all affected parties, as well as small-scale epidemiological surveys at the discovery location. The in-depth characterization is a midor long-term goal that involves the investigation of the virus pathogenicity, transmission experiments to explore modes of dispersal and possible vectors as well as large-scale surveys, organized on a national or international scale. A very interesting and universal technique for the in-depth characterization of a virus is the preparation of infectious clones. This requires the complete viral genome sequence, and it may offer valuable information about the ability of a virus to cause disease and the symptom development involved with the virus presence for individual viruses or for a mixture of viruses, while it can also support host range and transmissibility studies. This framework has already been actively followed by numerous research groups that focus on plant virology [215]. Regarding forest virology, however, as mentioned in the introduction, the progress is anticipated to be too slow, due to the few groups that focus on these issues, and if research in this field in not drastically financed, we may face unpleasant consequences in the future.

Based on the data of the last seven years, it has been revealed that the genetic variation of the forest virome is much larger than estimated. After gathering information about the viral presence in the holobionts, we could-as a next step-estimate the role of this virome in holobionts, the need for which was underlined by Rosenbeng and Zilber-Rosenberg [216]. One of the four basic principles of hologenome theory is that genetic variation in the hologenome can also be caused by changes in the microbiome genome [216]. In the following, we attempt to make suggestions on how the novel genetic information may qualitatively influence our view regarding forest health.

An important source of genetic variation is the horizontal gene transfer (HGT). As an example, 128 genes identified in the genome of moss Physcomitrella patens were acquired by HGT from prokaryotes, fungi or viruses [217]. Interestingly, many open reading frames (ORFs) showed high phylogenetic affinities to giant DNA viruses (nucleocytoplasmic large DNA viruses; NCLDV) homologues. It is found that the $P$. patens genes are clustered in 
DNA stretches (up to $13 \mathrm{~kb}$ ) containing up to $16 \mathrm{NCLDV-like} \mathrm{ORFs} \mathrm{[218].} \mathrm{The} \mathrm{acquisi-}$ tion of genomic segments by HGT has also been found in plants in relation to infections by pararetroviruses. With the use of HTS, two novel badnaviruses, which are dsDNA pararetroviruses of the family Caulimoviridae, were discovered in birch and chestnut and one unclassified Caulimoviridae member was discovered in pines. Pararetroviruses are often present as integrated, complete or fragmented and/or re-arranged genomic sequences in some host plant genomes and are then referred to as endogenous viral elements (EVEs). Some banana streak viruses (BSV) are found in episomal form with an endogenous counterpart (eBSV) [219]. In a few cases, badnavirus EVEs are known to be activated to generate viral infection (such as Banana streak OL, GF or IM viruses) [220]. Moreover, it is shown that genes of totiviruses and partitiviruses have widespread homologs in the nuclear genomes of eukaryotic organisms [221]. Evidence has been provided that some of the transferred genes are conserved and expressed in eukaryotic organisms, suggesting that these viral genes are also functional in the recipient genomes [221]. Whether the integration of the viral DNA of the novel caulimoviruses into the birch, chestnut and pine genome may play a role in its evolution remains to be untangled.

Viruses often coinfect single holobionts-in our study trees/shrubs-in nature. This was already known before the development of HTS technology, but the deep sequencing methods profoundly revealed the complexity of plants and tree viromes. Novel data on the birch virome clearly demonstrate in holobionts mixed infections by multiple plant viruses as well as multiple variants of the same virus species $[14,15,189]$. This is also the case in other non-forest plant species such as peach [222] or grapevine [223,224]. As a consequence, it is not easy to establish a correlation between such viral complexes and the appearance of symptoms or to differentiate symptomatology in cases of infection by a single virus or by two virus species. It is, however, suggested [189] that alterations in the viral communities in a holobiont may result in an alteration in symptom development.

Viruses often coinfect single fungal hosts in nature, and interesting virus-virus interplays in coinfected hosts have been reported that may be synergistic, apparently neutral or antagonistic [147]. Strong virus interference between unrelated RNA viruses was detected in Cryphonectria parasitica; for example, the (+)ssRNA virus Cryphonectria hypovirus 1 (CHV1) exerts a one-way synergistic effect on a co-infecting mycoreovirus 1 (MyRV1), resulting in enhanced virus accumulation and increased vertical transmission of MyRV1 [225]. In another interplay, the replication of Rosellinia necatrix victorivirus 1 (RnVV1) was strongly impaired by coinfection with MyRV1 or a mutant of CHV1 lacking the RNA silencing suppressor [170]. Recently, a unique mutualistic virus-virus interplay was reported, where the capsidless (+)ssRNA yado-kari virus (YkV1) was hosted by an unrelated dsRNA virus, yado-nushi virus (YnV1); while YnV1 could complete its replication cycle, YkV1 relied on YnV1 for its viability [226]. In another interaction system, the hypovirulence-associated mycoreovirus, named Sclerotinia sclerotiorum mycoreovirus 4 (SsMYRV4), could suppress host non-self-recognition and facilitate the horizontal transmission of heterologous viruses among vegetatively incompatible $S$. sclerotiorum individuals to create a bridge donor strain for mycovirus spread under natural conditions [227]. Such examples provide insight into the potential for broad-spectrum virus control mediated by RNA silencing.

Interspecific virus transmission is often suggested in mycoviruses [196,228]. In vitro experiments have shown that Cryphonectria hypovirus 1 was transmitted horizontally between the chestnut blight fungus Cryphonectria parasitica, and a sympatric unidentified Cryphonectria species via hyphal anastomosis [228]. Similarly, highly similar Heterobasidion RNA virus 1 (HetRV1) strains with 98\% nucleotide level similarity were found from $H$. parviporum and $H$. australe growing in the same region in Bhutan, an observation that suggests recent virus transmission between these taxonomically distant Heterobasidion species in nature [131]. In another host, Fraxinus spp., hyphal anastomosis and transfer of the mitovirus Hymenoscyphus fraxineus mitovirus 1 (HfMV1) between both Hymenoscyphus albidus and $H$. fraxineus in ash is also hypothesized [196]. Bearing in mind that interspecies 
virus transmission is possible between viruses occurring in distantly related organisms, such as viruses infecting fungi, plants, oomycetes and invertebrates $[229,230]$, this evolutionary potential should also be taken into consideration in view of the forest virome.

The efforts to untangle the complex world of the microbiota-virome interaction has been initiated for the human holobiont. Evidence is provided that bacteria aid in the antiviral response to certain viruses; however, occasionally, they may act as promoters of viral infection [231]. The present review constitutes a conceptual change by putting communities of microbiota and virome in a forest together. In this way, it becomes obvious how many possibilities for interactions are open, with all the consequences these may have for all "partners" within a holobiont. An important consequence could be that since the microbiome genome can adjust to environmental dynamics more rapidly and by more processes than the host genome, it can play a fundamental role in the adaptation and evolution of the holobiont [216].

The accumulation of knowledge regarding abundant mycoviruses in plant pathogenic fungi in forests offers new possibilities for pathogen control and management. It was previously found that endophytes could potentially be utilized as biocontrol agents in integrated pest and disease management [232]. Practical applications for forest protection based on endophytes are still rare. As stated above, the major mycoviral biocontrol agent used in field conditions is the Cryphonectria hypovirus 1 (CHV1), which significantly reduces the pathogenicity of the ascomycetous chestnut blight fungus (Cryphonectria parasitica) in Europe [167,168]. Moreover, in C. parasitica, the introduction of a partitivirus and a megabirnavirus originating from another host fungus, Rosellinia necatrix, was also shown to reduce host virulence $[233,234]$. Several $R$. necatrix viruses, including a fungal reovirus, also show potential for controlling their native host [235-238]. Additionally, Heterobasidion partitiviruses 13 and 15 have been shown to restrict host growth and alter the mycelial morphology of the conifer root rot fungi $H$. annosum and H. parviporum $[169,200]$. The recently generated data that are summarized in the present review could trigger further novel, modern, sustainable and environmentally friendly pest control applications.

In the present review, we did not address viruses of arthropods; however, it should be noted that baculoviruses of insect pests of temperate forest trees have been investigated for their biocontrol potential. The most prominent, which we mention here, are the nuclear polyhedrosis virus affecting Lymantria dispar on birches [239], oaks and poplars [240]; the Condylorrhiza vestigialis multiple nucleopolyhedrovirus affecting Condylorrhiza vestigialis on poplars [241]; the Orgyia leucostigma nucleopolyhedrovirus infesting Orgyia leucostigma on birches, firs and spruces [242,243]; and the Neodiprion abietis nucleopolyhedrovirus (NeseSNPV) affecting Neodiprion abietis on conifers [244]. As part of the effort to control the sawfly, NeseSNPV was introduced from Sweden into Canada and spread rapidly through the cohort and ultimately the population, resulting in the long-term suppression of $N$. sertifer [245]. To the best of our knowledge, HTS application has not contributed any further progress in this field.

Regarding vectors that transmit viruses, little is known. The only corresponding reference in the past was given in 1972 when Nienhaus detected tobamoviruses in Californian oak leaves [102] and experimentally assumed a virus transmissible fungus (Sphaerotheca lanestris). Vector studies of forest viruses were not reported until 2012 when Mielke and Mühlbach [16] highlighted the confirmed vector transmission by eriophyid mites (Phytoptus pyri) conclusively shown with several emaraviruses: European mountain ash ringspotassociated virus (EMARaV), fig mosaic virus (FMV), rose rosette virus (RRV), raspberry leaf blotch virus (RLBV) and pigeonpea sterility mosaic virus.

Healthy trees and healthy forests are translated into forests providing better regulating services (associated with natural catastrophes), maintenance/habitat services (increased biodiversity) and multiple ecosystem services (affecting humans and animals). However, the question arises as to how the "healthy forest virome" is defined, taking into consideration that virus-host relationships span the entire range from aggressive parasitism to mutualism. The corresponding question was previously posed concerning the "healthy 
human virome". In humans, the same virus can be either a symbiont or a pathogen depending on conditions such as the health status and developmental stage of the host. Koonin et al. [246] suggest that the boundary between symbiotic and pathogenic viruses is fluid, such that members of the healthy virome can become pathogens under changing conditions. Rather, the mode of virus-host interaction is a function of multiple factors, including environmental conditions and the host-virus population structure. They conclude that the healthy virome is heterogeneous and consists of three distinct components: a. viruses that systematically enter the human organism but do not replicate in humans; b. viruses infecting prokaryotes and, possibly, unicellular eukaryotes that comprise the healthy human microbiome; and c. viruses that actually replicate and persist in human cells. Similarly to human viruses, the relationship between a particular virus and its plant host can be rarely, if ever, defined by a single regime. Reviewed data from this study show that in a single holobiont, viruses may coexist that a. enter a tree host through their endophytic host (Table 2) or interact with the tree via their ectomycorrhizal or saprotroph fungal host (Table 3); b. directly enter the host and act as pathogenic or latent viral agents (Table 1); and/or c. can potentially be integrated into their tree host as EVEs (badnaviruses; see discussion above). We are, however, at a stage where we gather knowledge about viral occurrence in forests but are still far from defining the criteria for a "healthy forest virome". In light of approaching this definition, knowledge on different types of symbiotic viruses must catch up to that of pathogenic viruses.

The characterization of many novel - pathogenic or non-pathogenic-viruses in a short time raises the question of how to profit from these new data in order to avoid forest disease outbreaks in the future. It is possible for a pathogen to initiate an emerging infectious disease (EID)? According to the pathogen-host-environment interplay theory [247], emergence starts with an existing disease complex or pathogen-host-environment complex-based on paradigms from human and animal disease. The drivers of a pathogen's emergence cause a shift in the overall pattern of the pathogen-host-environment interactions, leading to an EID event. Examples of drivers in regard to a forest comprise deforestation and logging, human encroachment of forests and game reserves and increased interspecies contacts at the wildlife/agriculture interface. Impending climate change may support the spread of forest pathogens and diseases and play a role in the dispersal of forest epidemics. Based on significant changes in the environment, alterations in the interactions within the holobiont may underlie future outbreaks of diseases. In light of the current detrimental and on-going COVID-19 epidemic in humans, we propose that a driver analysis in forest pathogens should be conducted similarly across the fields of human, animal and plant health.

Author Contributions: Conceptualization, A.R.; investigation, A.R. and E.J.V.; writing—original draft preparation, A.R and E.J.V.; writing—-review and editing, C.B. All authors have read and agreed to the published version of the manuscript.

Funding: We acknowledge support from the German Research Foundation (DFG) and the Open Access Publication Fund of Humboldt-Universität zu Berlin. This work was also supported by the Academy of Finland (decision number 309896).

Acknowledgments: We are grateful to the team of the section Phytomedicine at Humboldt-Universität Berlin and, in particular, to Susanne von Bargen, Martina Bandte and Maria Landgraf, and to Andrea Klinke, Renate Junge and Gariele Buddruss for their technical assistance and contribution to the current knowledge of virus diseases in forest and urban trees gained in the last 20 years. Finally, we would like to thank anonymous reviewers for providing constructive comments that substantially contributed to the improvement of the manuscript.

Conflicts of Interest: The authors declare no conflict of interest. 


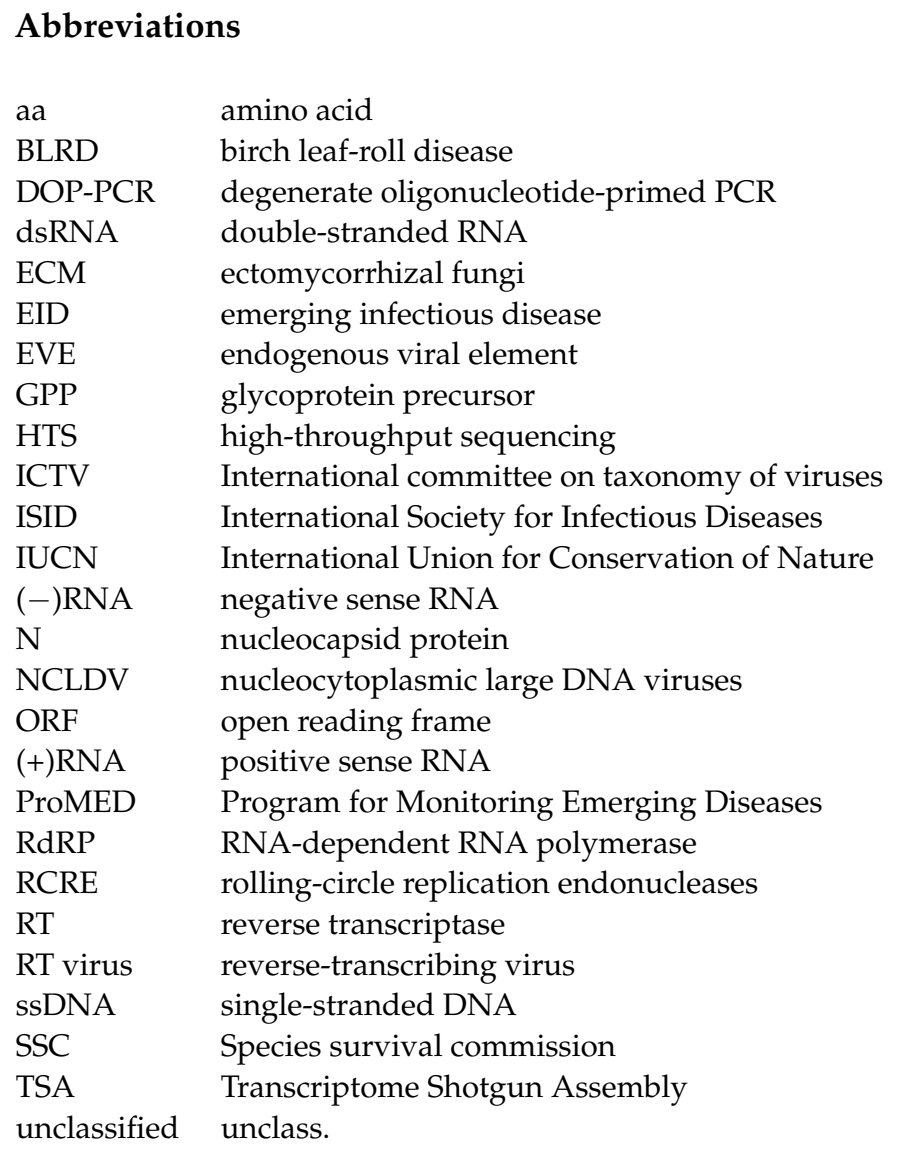

\section{References}

1. Forest Europe. The State of Europe's Forests 2020; Köhl, M., Linser, S., Prins, K., Eds.; Forest Europe Liaison Unit: Bratislava, Slovakia, 2020.

2. Lier, M.; Köhl, M.; Korhonen, K.T.; Linser, S.; Prins, K. Forest relevant targets in EU policy instruments-Can progress be measured by the pan-European criteria and indicators for sustainable forest management? For. Policy Econ. 2021, $128,102481$. [CrossRef]

3. Dolja, V.; Krupovic, M.; Koonin, E. Deep Roots and Splendid Boughs of the Global Plant Virome. Annu. Rev. Phytopathol. 2020, 58, 23-53. [CrossRef] [PubMed]

4. Ghabrial, S.A.; Castón, J.R.; Jiang, D.; Nibert, M.L.; Suzuki, N. 50-plus years of fungal viruses. Virology 2015, 479, 356-368. [CrossRef]

5. Büttner, C.; Nienhaus, F. Virus contamination of soils in forest ecosystems of the Federal Republic of Germany. Eur. J. For. Pathol. 1989, 19, 47-53. [CrossRef]

6. Büttner, C.; von Bargen, S.; Bandte, M.; Mühlbach, H.-P. Forest diseases caused by viruses. In Infectious Forest Diseases; Gonthier, P., Nicolotti, G., Eds.; CABI: Wallingford, UK, 2013; pp. 50-75.

7. Bebber, D.P. Range-Expanding Pests and Pathogens in a Warming World. Ann. Rev. Phytopathol. Ann. Rev. 2015, 53, 335-356. [CrossRef]

8. Roossinck, M.J.; Martin, D.P.; Roumagnac, P. Plant virus metagenomics: Advances in virus discovery. Phytopathology 2015, 105, 716-727. [CrossRef] [PubMed]

9. Vainio, E.J.; Jurvansuu, J.; Streng, J.; Rajamäki, M.L.; Hantula, J.; Valkonen, J. Diagnosis and discovery of fungal viruses using deep sequencing of small RNAs. J. Gen. Virol. 2015, 96, 714-725. [CrossRef]

10. Zhang, Y.Z.; Shi, M.; Holmes, E.C. Using metagenomics to characterize an expanding virosphere. Cell 2018, $172,1168-1172$. [CrossRef]

11. Villamor, D.E.V.; Ho, T.; Al Rwahnih, M.; Martin, R.R.; Tzanetakis, I.E. High throughput sequencing for plant virus detection and discovery. Phytopathology 2019, 109, 716-725. [CrossRef]

12. von Bargen, S.; Grubits, E.; Jalkanen, R.; Buettner, C. Cherry leaf roll virus-an emerging virus in Finland? Silva Fenn. 2009, 43, 727-738. [CrossRef]

13. Rumbou, A.; von Bargen, S.; Demiral, R.; Langer, J.; Rott, M.; Jalkanen, R.; Büttner, C. High genetic diversity at the inter-/intra-host level of Cherry leaf roll virus population associated with the birch leaf-roll disease in Fennoscandia. Scand. J. For. Res. 2016, 31, 546-560. [CrossRef] 
14. Rumbou, A.; Candresse, T.; Marais, A.; Svanella-Dumas, L.; Landgraf, M.; von Bargen, S.; Büttner, C. Unravelling the virome in birch: RNA-Seq reveals a complex of known and novel viruses. PLoS ONE 2020, 15, e0221834. [CrossRef]

15. Rumbou, A.; Candresse, T.; Marais, A.; Theil, S.; Langer, J.; Jalkanen, R.; Büttner, C. A novel badnavirus discovered from Betula sp. affected by birch leaf-roll disease. PLoS ONE 2018, 13, e0193888. [CrossRef]

16. Mielke-Ehret, N.; Mühlbach, H.-P. Emaravirus: A novel genus of multipartite, negative strand RNA plant viruses. Viruses 2012, 4, 1515-1536. [CrossRef] [PubMed]

17. Robel, J.; Dieckmann, L.; von Bargen, S.; Büttner, C. First detection of European mountain ash ringspot associated virus in rowan trees in Scotland. New Dis. Rep. 2013, 27, 13. [CrossRef]

18. von Bargen, S.; Bandte, M.; Al Kubrusli, R.; Jalkanen, R.; Büttner, C. First report of European mountain ash ringspot-associated virus in Karpatiosorbus $\times$ hybrida in Finland. New Dis. Rep. 2020, 42, 1. [CrossRef]

19. von Bargen, S.; Dieckmann, H.-L.; Candresse, T.; Mühlbach, H.-P.; Roßbach, J.; Büttner, C. Determination of the complete genome sequence of European mountain ash ringspot-associated emaravirus from Sorbus intermedia reveals two additional genome segments. Arch. Virol. 2019, 164, 1937-1941. [CrossRef]

20. von Bargen, S.; Tischendorf, M.; Büttner, C. First report of European mountain ash ringspot-associated virus in serviceberry (Amelanchier spp.) in Germany. New Dis. Rep. 2018, 37, 19. [CrossRef]

21. Marzano, S.-Y.L.; Nelson, B.D.; Ajayi-Oyetunde, O.; Bradley, C.A.; Hughes, T.J.; Hartman, G.L.; Eastburn, D.M.; Domier, L.L. Identification of diverse mycoviruses through metatranscriptomics characterization of the viromes of five major fungal plant pathogens. J. Virol. 2016, 90, 6846-6863. [CrossRef]

22. Roossinck, M.J. Lifestyles of plant viruses. Philosoph. Trans. Roy. Soc. B Biol. Sci. 2010, 365, 1899-1905. [CrossRef] [PubMed]

23. Margulis, L. Symbiosis in Cell Evolution, 2nd ed.; W. H. Freeman \& Co.: New York, NY, USA, 1993.

24. Maliogka, V.I.; Minafra, A.; Saldarelli, P.; Ruiz-García, A.B.; Glasa, M.; Katis, N.; Olmos, A. Recent Advances on Detection and Characterization of Fruit Tree Viruses Using High-Throughput Sequencing Technologies. Viruses 2018, 10, 436. [CrossRef]

25. Hou, W.; Li, S.; Massart, S. Is There a "Biological Desert" With the Discovery of New Plant Viruses? A Retrospective Analysis for New Fruit Tree Viruses. Front. Microbiol. 2020, 11, 592816. [CrossRef]

26. Rosenberg, E.; Zilber-Rosenberg, I. The Hologenome Concept: Human, Animal and Plant Microbiota; Springer: Dordrecht, The Netherlands, 2013; ISBN 978-3-319-04241-1.

27. Rosenberg, E.; Zilber-Rosenberg, I. Microbes Drive Evolution of Animals and Plants: The Hologenome Concept. MBio 2016, 7, e01395. [CrossRef]

28. Vandenkoornhuyse, P.; Quaiser, A.; Duhamel, M.; Le Van, A.; Dufresne, A. The importance of the microbiome of the plant holobiont. New Phytol. 2015, 206, 1196-1206. [CrossRef] [PubMed]

29. Sweet, J.B. Fruit tree virus infections of woody exotic and indigenous plants in Britain. Acta Phytopathol. Acad. Sci. Hung. 1980, 15, 231-238. [CrossRef]

30. Bandte, M.; Von Bargen, S.; Arndt, N.; Grubits, E.; Jalkanen, R.; Büttner, C. Bedeutende Viren an Birke-Fallbeispiele aus Deutschland, Finnland und den USA. In DUJESIEFKEN, D. (Hrsg.): Jahrbuch der Baumpflege; Haymarket Media: Braunschweig, Germany, 2009; pp. 215-221.

31. Polák, Z.; Zieglerová, J. Spontaneous occurrence of apple mosaic virus in some forest and ornamental woody species. In Proceedings of the Fourteenth Slovak and Czech Plant Protection Conference (Slovak Republic), 3-4 September; Cagan, L., Praslicka, J., Eds.; Slovak University of Agriculture: Nitra, Slovakia, 1997; pp. 87-88.

32. Hardcastle, T.; Gotlieb, A.R. An enzyme-linked immunosorbent assay for the detection of apple mosaic virus in yellow birch. Can. J. For. Res. 1980, 10, 278-283. [CrossRef]

33. Baumann, G.; Casper, R.; Converse, R.H. The occurrence of apple mosaic virus in red and black raspberry and in blackberry cultivars. Acta Hortic. 1982, 129, 13-20. [CrossRef]

34. Grimová, L.; Winkowska, L.; Konrady, M.; Ryšánek, P. Apple mosaic virus. Phytopathol. Mediterran. 2016, 55, 1-19.

35. Cooper, J.I.; Massalski, P.R. Viruses and virus-like diseases affecting Betula spp. Proc. R. Soc. Edinb. 1984, 85B, 183-195. [CrossRef]

36. Cooper, J.I.; Sweet, J.B. The detection of viruses with nematode vectors in six woody hosts. Forestry 1976, 49, 73-78. [CrossRef]

37. Cooper, J.I.; Edwards, M.L.; Arnold, M.K.; Massalski, P.R. A tobravirus that invades Fraxinus mariesii in the United Kingdom. Plant Pathol. 1983, 32, 469-472. [CrossRef]

38. Nienhaus, F.; Hamacher, J. Virosen in Eschen. Allg. Forstzeitg. 1990, 16, 385-386.

39. Martin, R.R.; MacFarlane, S.; Sabanadzovic, S.; Quito, D.; Poudel, B.; Tzanetakis, I.E. Viruses and Virus Diseases of Rubus. Plant Dis. Sci. Soc. 2012, 97, 168-182. [CrossRef]

40. Thomas, P.R. Host status of some plants for Xiphinema diversicaudatum (Micol.) and their susceptibility to viruses transmitted by this species. Ann. Appl. Biol. 1970, 65, 169-178. [CrossRef]

41. Erdiller, G. Acer virus diseases in Turkey. J. Turk. Phytopathol. 1986, 15, 46-59.

42. von Bargen, S.; Al Kubrusli, R.; Gaskin, T.; Fürl, S.; Hüttner, F.; Blystad, D.-R.; Karlin, D.G.; Jalkanen, R.; Büttner, C. Characterisation of a novel Emaravirus identified in mosaic-diseased Eurasian aspen (Populus tremula). Ann. Appl. Biol. 2020, 176, $210-222$. [CrossRef]

43. Lawrence, D.M.; Rozanov, M.N.; Hillman, B.I. Autocatalytic processing of the 223-kDa protein of blueberry scorch carlavirus by a papain-like proteinase. Virology 1995, 207, 127-135. [CrossRef] 
44. Kalinowska, E.; Paduch-Cichal, E.; Chodorska, M. First Report of Blueberry scorch virus in Elderberry in Poland. Plant Dis. 2013, 97, 1515. [CrossRef] [PubMed]

45. Kopp, R.F.; Castello, J.D.; Abrahamson, L.P. Viruses in Salix grown for bioenergy. Eur. J. For. Pathol. 1999, $29,117-122$.

46. Cooper, J.I.; Atkinson, M.A. Cherry leaf roll virus causing a disease of Betula spp. in the United Kingdom. Forestry 1975, 48, 193-203. [CrossRef]

47. Hamacher, J.; Quadt, A. Light- and electron microscopic studies of Cherry leaf roll virus (CLRV) on European ash (Fraxinus excelsior L.). J. Phytopathol. 1991, 131, 215-226. [CrossRef]

48. Büttner, C.; von Bargen, S.; Bandte, M.; Myrta, A. Cherry leaf roll virus. In Virus and Virus-Like Diseases of Pome and Stone Fruits; Hadidi, A., Barba, M., Candresse, T., Jelkmann, W., Eds.; APS PRESS: St. Paul, MN, USA, 2011.

49. Ellis, P.J.; Converse, R.H.; Stace-Smith, R. Viruses of Sambucus canadensis in North America. Acta Hortic. 1992, 308, 69-80. [CrossRef]

50. Hansen, A.J.; Stace-Smith, R. Properties of virus isolated from golden elderberry, Sambucus nigra aurea. Phytopathology 1971, 61, 1222-1229. [CrossRef]

51. Rebenstorf, K.; Candresse, T.; Dulucq, M.J.; Büttner, C.; Obermeier, C. Host species-dependent population structure of a pollen-borne plant virus, Cherry leaf roll virus. J. Virol. 2006, 80, 2453-2462. [CrossRef]

52. Cherry Leaf Roll Virus. [Distribution map]. In Distribution Maps of Plant Diseases; Map 800 (Edition 2); CABI: Wallingford, UK, 2014. [CrossRef]

53. von Bargen, S.; Langer, J.; Robel, J.; Rumbou, A.; Büttner, C. Complete nucleotide sequence of Cherry leaf roll virus (CLRV), a subgroup C nepovirus. Virus Res. 2012, 163, 678-683. [CrossRef] [PubMed]

54. Villamor, D.E.V.; Eastwell, K.C. Sambucus nigra subsp. caerulea and Malva spp.: Newly identified hosts of cherry rasp leaf virus. Plant Dis. Sci. Soc. 2015, 100, 867. [CrossRef]

55. Marais, A.; Murolo, S.; Faure, C.; Brans, Y.; Larue, C.; Maclot, F.; Massart, S.; Chiumenti, M.; Minafra, A.; Romamazzi, G.; et al. Sixty years from the first disease description, a novel badnavirus associated with chestnut mosaic disease. Phytopathology 2020. [CrossRef] [PubMed]

56. Bandte, M.; Rehanek, M.; Leder, B.; von Bargen, S.; Buettner, C. Identification of an emaravirus in a common Oak (Quercus robur L.) Conservation seed orchard in Germany: Implications for Oak health. Forests 2020, 11, 1174. [CrossRef]

57. Rehanek, M.; von Bargen, S.; Bandte, M.; Karlin, D.G.; Büttner, C. A novel emaravirus comprising five RNA segments is associated with ringspot disease in oak. Arch. Virol. 2021, 166, 987-990. [CrossRef]

58. Šafářová, D.; Vavroušková, K.; Candresse, T.; Navrátil, M. Molecular characterization of a novel Aureusvirus infecting elderberry (Sambucus nigra L.). PLoS ONE 2018, 13, e0200506. [CrossRef]

59. Ho, T.; Tzanetakis, I.E. Development of a virus detection and discovery pipeline using next generation sequencing. Virology 2014, 471-473, 54-60. [CrossRef] [PubMed]

60. Ho, T.; Quito-Avila, D.; Keller, K.E.; Postman, J.D.; Martin, R.R.; Tzanetakis, I.E. Evidence of sympatric speciation of elderberry carlaviruses. Virus Res. 2016, 215, 72-75. [CrossRef]

61. Jurke, I.; von Bargen, S.; Rumbou, A.; Büttner, C. Detection of Elm mottle virus (EMoV) and a putative novel Carlavirus in the genus Ulmus in northern Germany. In Proceedings of the 125th IUFRO Anniversary World Congress, Freiburg, Germany, 18-22 September 2017.

62. Rumbou, A.; von Bargen, S.; Buettner, C. Virus discovery using NGS in trees from urban/forest ecosystems. In Proceedings of the 1st COST Action FA1407-DIVAS, Ljubljana, Slovenia, 16-18 November 2015.

63. Rumbou, A.B. Sequence analysis and taxonomic determination of uncharacterized viruses identified by RNA-Seq in Betula species from Germany and Finland. In Proceedings of the 2nd COST Action FA1407-DIVAS, Thessaloniki, Greece, 11-13 April 2016.

64. Jones, A.T.; Mayo, M.A. Purification and properties of elm mottle virus. Ann. Appl. Biol. 1973, 74, 211-217. [CrossRef]

65. Jones, A.T. Elm Mottle Virus; CMI/AAB Descriptions of Plant Viruses No. 139; Commonwealth Mycological Institute: Kew, Surrey, UK; Association of Applied Biologists: Wellsbourne, Warwick, UK, 1974.

66. Scott, S.W.; Zimmerman, M.T.; Ge, X. Viruses in subgroup 2 of the genus Ilarvirus share both serological relationships and characteristics at the molecular level. Arch. Virol. 2003, 148, 2063-2075. [CrossRef]

67. Roßbach, J.; Dieckmann, H.L.; Büttner, T.; Mühlbach, H.P.; von Bargen, S.; Büttner, C. Genetic variability and phylogeny of European mountain ash ringspot-associated virus RNA3 and RNA4. Forests 2015, 6, 4072-4087. [CrossRef]

68. Grimová, L.; Marek, M.; Konrady, M.; Ryšánek, P. Newly identified host range of European mountain ash ringspot-associated virus (EMARaV) and its distribution in the Czech Republic. For. Pathol. 2015, 45, 177-189. [CrossRef]

69. Harju, V.; Adams, I.; Flint, L.; Jackson, L.; Fowkes, A.; Skelton, A.; Forde, S.; Fairless, N.; Field, C.; Marsden, S.; et al. A follow-up report regarding new hosts and distribution of European mountain ash ringspot-associated virus in Sorbus spp. in England. New Dis. Rep. 2017, 13. [CrossRef]

70. Valkonen, J.P.T.; Rännäli, M. First Report of European mountain ash ringspot-associated virus in Sorbus aucuparia from Eastern Karelia, Russia. Plant Dis. 2010, 94, 921. [CrossRef] [PubMed]

71. von Bargen, S.; Arndt, N.; Robel, J.; Jalkanen, R.; Büttner, C. Detection and genetic variability of European mountain ash ringspot-associated virus (EMARaV) in Sweden. For. Pathol. 2013, 43, 429-432. 
72. Druciarek, T.; Lewandowski, M.; Tzanetakis, I.E. First report of European mountain ash ringspot-associated emaravirus in Sorbus aucuparia in Poland. Plant Dis. 2019, 103, 166. [CrossRef]

73. von Bargen, S.; Büttner, T.; Mühlbach, H.-P.; Robel, J.; Büttner, C. First report of European mountain ash ringspot-associated virus in Sorbus aucuparia in Norway. Plant Dis. 2014, 98, 700. [CrossRef]

74. Rumbou, A.; Candresse, T.; von Bargen, S.; Büttner, C. Next-generation sequencing reveals a novel emaravirus in diseased maple trees from a German urban forest. Front. Microbiol. 2021, 11, 621179. [CrossRef]

75. Stefanac, Z.; Bezic, N.; Milicic, D. Some new data on Robinia mosaic cucumovirus. Acta Bot. Croat. 1988, 47, 1-5.

76. Pilotti, M.; Barba, M. Robinia mosaic virus: A new cucumovirus in Italy. (Il virus del mosaico della robinia: Un nuovo cucumovirus in Italia.). Petria 1993, 3, 161-168.

77. Amid-Motlagh, M.H.; Massumi, H.; Heydarnejad, J.; Mehrvar, M.; Hajimorad, M.R. Nucleotide sequence analyses of coat protein gene of peanut stunt virus isolates from alfalfa and different hosts show a new tentative subgroup from Iran. Virus Dis. 2017, 28, 295-302. [CrossRef]

78. Bang, J.H.; Choi, J.K.; Lee, S.Y. Characterization of Peanut stunt virus isolated from black locust tree (Robinia pseudoacacia L.). Plant Pathol. J. 2006, 22, 125-130. [CrossRef]

79. Rastrojo, A.; Núñez, A.; Moreno, D.A.; Alcamí, A. A new putative Caulimoviridae genus discovered through air metagenomics. Microbiol. Resour. Announc. 2018, 7, e00955-18. [CrossRef]

80. Nibert, M.L.; Pyle, J.D.; Firth, A.E. A +1 ribosomal frameshifting motif prevalent among plant amalgaviruses. Virology 2016, 498, 201-208. [CrossRef]

81. Veliceasa, D.; Enünlü, N.; Kós, P.B.; Köster, S.; Beuther, E.; Morgun, B.; Deshmukh, S.D.; Lukács, N. Searching for a New Putative Cryptic Virus in Pinus sylvestris L. Virus Genes 2006, 32, 177-186. [CrossRef] [PubMed]

82. Smith, C.M.; Campbell, M.M. Complete nucleotide sequence of the genomic RNA of poplar mosaic virus (Genus Carlavirus). Arch. Virol. 2004, 149, 1831-1841. [CrossRef] [PubMed]

83. Werner, R.; Mühlbach, H.-P.; Büttner, C. Detection of Poplar Mosaic Carlavirus (POPMV) by Immuno-Capture RT-PCR. In Diagnosis and Identification of Plant Pathogens; Proc. Symposium of European Foundation for Plant Pathology, Bonn, Germany; Dehne, H.-W., Adam, G., Diekmann, M., Frahm, J., Mauler-Machnik, A., van Halteren, P., Eds.; Springer: Dordrecht, The Netherlands, 1997; pp. 403-405. [CrossRef]

84. Smith, C.M.; Campbell, M.M. Populus genotypes differ in infection and systemic spread of poplar mosaic virus (PopMV). Plant Pathol. 2004, 53, 780-787. [CrossRef]

85. Šafářová, D.; Candresse, T.; Navrátil, M. Complete genome sequence of a novel bromovirus infecting elderberry (Sambucus nigra L.) in the Czech Republic. Arch. Virol. 2018, 163, 567-570. [CrossRef] [PubMed]

86. Borodynko, N.; Hasiów, B.; Figlerowicz, M.; Pospieszny, H. Identification of the new strain of Strawberry latent ringspot virus isolated from black locust (Robinia pseudoacacia L.). J. Phytopathol. 2007, 155, 738-742. [CrossRef]

87. Hentsch, T.; Fuchs, E.; Grüntzig, M. Das Strawberry latent ringspot nepovirus (SLRSV) an Aesculus hippocastanum L. [Strawberry latent ringspot nepovirus (SLRSV) on Aesculus hippocasta- num L.]. Arch. Phytopathol. Plant Protect. 1997, 31, 13-23. [CrossRef]

88. Schmelzer, K.; Schmidt, H.E. Untersuchungen an Viren der Zier- und Wildgeholze 6. Mitteilung: Erganzende Befunde an Caryopteris, soirce Virosen an Philadelphus, Aristolochia, Buddleia, Lycium und Aesculus. Phytopathol. Z. 1968, 66, 105-126. [CrossRef]

89. Dullemans, A.M.; Botermans, M.; de Kock, M.J.D.; de Krom, C.E.; van der Lee, T.A.J.; Roenhorst, J.W.; Stulemeijer, I.J.E.; Verbeek, M.; Westenberg, M.; van der Vlugt, R.A.A. Creation of a new genus in the family Secoviridae substantiated by sequence variation of newly identified strawberry latent ringspot virus isolates. Arch. Virol. 2020, 165, 21-31. [CrossRef]

90. Pospieszny, H.; Borodynko, N.; Jończyk, M. First report of Tomato black ring virus (TBRV) in the natural infection of Sambucus nigra in Poland. J. Plant Prot. Res. 2004, 44, 373-376.

91. Uyemoto, J.K.; Gilmer, R.M.; Williams, E. Sap-transmissible viruses of elderberry in New York. Plant Dis. Rep. 1971, 55, 913-916.

92. Polak, Z.; Prochazkova, Z.; Branisova, H. Recent findings of viruses of forest trees on the territory of the Czech Republic. Arch. Phytopathol. Pfl. 1990, 26, 389-393. [CrossRef]

93. Jacobi, V.; Castello, J.D. Infection of red spruce, black spruce, and balsam fir seedlings with tomato mosaic virus. Can. J. For. Res. 1992, 22, 919-924. [CrossRef]

94. Castello, J.D.; Wargo, P.M.; Jacobi, V.; Bachand, G.D.; Tobi, D.R.; Rogers, M.A.M. Tomato mosaic virus infection of red spruce on Whiteface Mountain, New York: Prevalence and potential impact. Can. J. For. Res. 1995, 25, 1340-1345. [CrossRef]

95. Varney, E.H.; Moore, J.D. Strain of tomato ringspot virus from American elm. Phytopathology 1952, 42, 476-477.

96. Ferris, M.A.; Castello, J.D. Detection of tomato ringspot virus in white ash and adjacent vegetation in central New York. Can. J. For. Res. 1988, 18, 813-817. [CrossRef]

97. Lana, A.O.; Agrios, G.N. Properties of a strain of tobacco mosaic virus isolated from white ash trees. Phytopathology 1974, 64, 1490-1495. [CrossRef]

98. Castello, J.D.; Amico, L.A.; O'Shea, M.T. Detection of tobacco mosaic and tobacco ringspot viruses in white ash trees by enzyme-linked immunosorbent assay. Plant Dis. 1984, 68, 787-790. [CrossRef]

99. Shiel, P.J.; Castello, J.D. Detection of tobacco mosaic and tobacco ringspot viruses in herbaceous and woody plants near virusinfected white ash trees in central New York. Plant Dis. 1985, 69, 791-795.

100. Yarwood, C.E.; Hecht-Poinar, E. A virus resembling tobacco mosaic virus in oak. Phytopathology 1970, 60, 1320. 
101. Amico, L.A.; O'Shea, M.T.; Castello, J.D.; Hibben, C.R. Transmission of tobacco mosaic and tobacco ringspot viruses from Moraine ash in New York. Plant Dis. 1985, 69, 542. [CrossRef]

102. Nienhaus, F.; Yarwood, C.E. Transmission of virus from oak leaves fractionated with Sephadex. Phytopathology 1972, 62, 313-315. [CrossRef]

103. Horvath, J.; Eke, I.; Gal, T.; Dezsery, M. Demonstration of virus-like particles in sweet chestnut and oak with leaf deformations in Hungary. Z. Pflanzenkrankh. Pflanzenschutz 1975, 82, 498-502.

104. Nienhaus, F. Viruses and suspected viruses in diseased oaks (Quercus robur and Quercus sessiliflora). Z. Pflanzenkrankh. Pflanzenschutz 1975, 85, 739-749.

105. Casalicchio, G. Punctation in chloro-necrotic ash. Monti Boschi 1965, 16, 39-46.

106. Hibben, C.R.; Bozarth, R.F.; Reese, J. Identification of tobacco necrosis virus in deteriorating clones of aspen. For. Sci. 1979, 25, 557-567.

107. Nienhaus, F. Infectious diseases in forest trees caused by viruses, mycoplasma-like organisms and primitive bacteria. Experientia 1985, 41, 597-603. [CrossRef]

108. Schmelzer, K. Viruses of Populus and Sambucus. In: Studies on viruses of ornamental and wild shrubs. Phytopathol. Z. 1966, 55, 311-351.

109. Hibben, C.R.; Bozarth, B.F. Identification of an ash strain of Tobacco ringspot virus. Phytopathology 1972, 62, 1023-1029. [CrossRef]

110. Hibben, C.R.; Walker, J.T. Nematode transmission of the ash strain of tobacco ringspot virus. Plant Dis. Rep. 1971, 55, 475-478.

111. Bertioli, D.J.; Hayle, A.; Cooper, J.I. A new virus isolated from an ash tree with dieback. J. Phytopathol. 1993, 139, 367-372. [CrossRef]

112. Murant, A.F.; Jones, A.T.; Martelli, G.P.; Stace-Smith, R. Nepoviruses: General, properties, diseases and virus identification. In The Plant Viruses; Harrison, B.D., Murant, A.F., Eds.; Springer Science \& Business Media: New York, NY, USA, 1996 ; pp. 139-186.

113. Machado, J.; Lockhart, B.E.; Smith, J. White ash mosaic virus, a previously undescribed flexivirus occurring in Fraxinus spp. in North America. Phytopathology 2006, 96, S67.

114. Machado-Caballero, J.E.; Lockhart, B.; Mason, S.L.; Mollov, D.; Smith, J.A. Identification, Transmission, and Partial Characterization of a Previously Undescribed Flexivirus Causing a Mosaic Disease of Ash (Fraxinus spp.) in the USA. Plant Health Prog. 2013, 14, 21. [CrossRef]

115. Bratsch, S.A.; Lockhart, B.E.; Mollov, D.S.; Tisserat, N.A. Partial characterization of two new viruses in ash belonging to the families Partitiviridae and Caulimoviridae. Acta Hortic. 2018, 1191, 89-96. [CrossRef]

116. Linnakoski, R.; Sutela, S.; Coetzee, M.; Duong, T.A.; Pavlov, I.N.; Litovka, Y.A.; Hantula, J.; Wingfield, B.D.; Vainio, E.J. Armillaria root rot fungi host single-stranded RNA viruses. Sci. Rep. 2021, 11, 7336. [CrossRef]

117. Liu, J.J.; Chan, D.; Xiang, Y.; Williams, H.; Li, X.R.; Sniezko, R.A.; Sturrock, R.N. Characterization of Five Novel Mitoviruses in the White Pine Blister Rust Fungus Cronartium ribicola. PLoS ONE 2016, 11, e0154267. [CrossRef] [PubMed]

118. Romon-Ochoa, P.; Gorton, C.; Lewis, A.; van der Linde, S.; Webber, J.; Pérez-Sierra, A. Hypovirulent effect of the Cryphonectria hypovirus 1 in British isolates of Cryphonectria parasitica. Pest Manag. Sci. 2020, 76, 1333-1343. [CrossRef]

119. Krstin, L.; Katanić, Z.; Repar, J.; Ježić, M.; Kobaš, A.; Ćurković-Perica, M. Genetic Diversity of Cryphonectria hypovirus 1, a Biocontrol Agent of Chestnut Blight, in Croatia and Slovenia. Microb. Ecol. 2020, 79, 148-163. [CrossRef] [PubMed]

120. Diamandis, S.; Perlerou, C.; Tziros, G.; Christopoulos, V.; Topalidou, E. Establishment and dissemination of hypovirulent strains of Cryphonectria parasitica in Greece. For. Path. 2015, 45, 408-414. [CrossRef]

121. Çeliker, N.M.; Onogur, E. Evaluation of hypovirulent isolates of Cryphonectria parasitica for the biological control of chestnut blight in Turkey. For. Snow Landsc. Res. 2001, 76, 378-382.

122. Nuskern, L.; Ježić, M.; Liber, Z.; Mlinarec, J.; Ćurković-Perica, M. Cryphonectria hypovirus 1-Induced Epigenetic Changes in Infected Phytopathogenic Fungus Cryphonectria parasitica. Microb. Ecol. 2018, 75, 790-798. [CrossRef]

123. Choi, G.H.; Nuss, D.L. Hypovirulence of chestnut blight fungus conferred by an infectious viral cDNA. Science 1992, 257, 800-803. [CrossRef]

124. Double, M.L.; Jarosz, A.M.; Fulbright, D.W.; Davelos Baines, A.; MacDonald, W.L. Evaluation of Two Decades of Cryphonectria parasitica Hypovirus Introduction in an American Chestnut Stand in Wisconsin. Phytopathology 2018, 108, 702-710. [CrossRef]

125. Forgia, M.; Isgandarli, E.; Aghayeva, D.N.; Huseynova, I.; Turina, M. Virome characterization of Cryphonectria parasitica isolates from Azerbaijan unveiled a new mymonavirus and a putative new RNA virus unrelated to described viral sequences. Virology 2021, 553, 51-61. [CrossRef]

126. Polashock, J.J.; Hillman, B.I. A small mitochondrial double-stranded (ds) RNA element associated with a hypovirulent strain of the chestnut blight fungus and ancestrally related to yeast cytoplasmic T and W dsRNAs. Proc. Natl. Acad. Sci. USA 1994, 91, 8680-8684. [CrossRef]

127. Vainio, E.J.; Hantula, J. Taxonomy, biogeography and importance of Heterobasidion viruses. Virus Res. 2016, 219, 2-10. [CrossRef]

128. Vainio, E.J. Mitoviruses in the conifer root rot pathogens Heterobasidion annosum and H. parviporum. Virus Res. 2019, $271,197681$. [CrossRef] [PubMed]

129. Vainio, E.J.; Hyder, R.; Aday, G.; Hansen, E.; Piri, T.; Dogmus-Lehtijärvi, T.; Lehtijärvi, A.; Korhonen, K.; Hantula, J. Population structure of a novel putative mycovirus infecting the conifer root-rot fungus Heterobasidion annosum sensu lato. Virology 2012, 422, 366-376. [CrossRef] 
130. Hyder, R.; Pennanen, T.; Hamberg, L.; Vainio, E.J.; Piri, T.; Hantula, J. Two viruses of Heterobasidion confer beneficial, cryptic or detrimental effects to their hosts in different situations. Fungal Ecol. 2013, 6, 387-396. [CrossRef]

131. Vainio, E.J.; Hakanpää, J.; Dai, Y.C.; Hansen, E.; Korhonen, K.; Hantula, J. Species of Heterobasidion host a diverse pool of partitiviruses with global distribution and interspecies transmission. Fungal Biol. 2011, 115, 1234-1243. [CrossRef] [PubMed]

132. Vainio, E.J.; Korhonen, K.; Tuomivirta, T.T.; Hantula, J. A novel putative partitivirus of the saprotrophic fungus Heterobasidion ecrustosum infects pathogenic species of the Heterobasidion annosum complex. Fungal Biol. 2010, 114, 955-965. [CrossRef]

133. Vainio, E.J.; Piri, T.; Hantula, J. Virus community dynamics in the conifer pathogenic fungus Heterobasidion parviporum following an artificial introduction of a partitivirus. Microb. Ecol. 2013, 65, 28-38. [CrossRef] [PubMed]

134. Vainio, E.; Müller, M.; Korhonen, K.; Piri, T.; Hantula, J. Viruses accumulate in aging infection centers of a fungal forest pathogen. J. ISME 2015, 9, 497-507. [CrossRef]

135. Kashif, M.; Hyder, R.; De Vega Perez, D.; Hantula, J.; Vainio, E.J. Heterobasidion wood decay fungi host diverse and globally distributed viruses related to Helicobasidium mompa partitivirus V70. Virus Res. 2015, 195, 119-123. [CrossRef]

136. Vainio, E.J.; Chiba, S.; Ghabrial, S.A.; Maiss, E.; Roossinck, M.; Sabanadzovic, S.; Suzuki, N.; Xie, J.; Nibert, M. ICTV Report Consortium. ICTV Virus Taxonomy Profile: Partitiviridae. J. Gen. Virol. Microbiol. Soc. 2018, 99, 17-18. [CrossRef]

137. Vainio, E.J.; Capretti, P.; Motta, E.; Hantula, J. Molecular characterization of HetRV8-ir1, a partitivirus of the invasive conifer pathogenic fungus H. irregulare. Arch. Virol. 2013, 158, 1613-1615. [CrossRef]

138. Schoebel, C.N.; Zoller, S.; Rigling, D. Detection and genetic characterisation of a novel mycovirus in Hymenoscyphus fraxineus, the causal agent of ash dieback. Infect. Genet. Evolut. 2014, 28, 78-86. [CrossRef] [PubMed]

139. Martínez-Álvarez, P.; Vainio, E.J.; Botella, L.; Hantula, J.; Diez, J.J. Three mitovirus strains infecting a single isolate of Fusarium circinatum are the first putative members of the family Narnaviridae detected in a fungus of the genus Fusarium. Arch. Virol. 2014, 159, 2153-2155. [CrossRef] [PubMed]

140. Vainio, E.J.; Martínez-Álvarez, P.; Bezos, D.; Hantula, J.; Diez, J.J. Fusarium circinatum isolates from northern Spain are commonly infected by three distinct mitoviruses. Arch. Virol. 2015, 160, 2093-2098. [CrossRef] [PubMed]

141. Muñoz-Adalia, E.J.; Diez, J.J.; Fernández, M.M.; Hantula, J.; Vainio, E.J. Characterization of small RNAs originating from mitoviruses infecting the conifer pathogen Fusarium circinatum. Arch. Virol. 2018, 163, 1009-1018. [CrossRef]

142. Tuomivirta, T.; Hantula, J. Gremmeniella abietina mitochondrial RNA virus S1 is phylogenetically related to the members of the genus Mitovirus. Arch. Virol. 2003, 148, 2429-2436. [CrossRef]

143. Tuomivirta, T.T.; Hantula, J. Three unrelated viruses occur in a single isolate of Gremmeniella abietina var. abietina type A. Virus Res. 2005, 110, 31-39. [CrossRef]

144. Botella, L.; Vainio, E.J.; Hantula, J.; Diez, J.J.; Jankovsky, L. Description and prevalence of a putative novel mycovirus within the conifer pathogen Gremmeniella abietina. Arch. Virol. 2015, 160, 1967-1975. [CrossRef] [PubMed]

145. Tuomivirta, T.T.; Kaitera, J.; Hantula, J. A novel putative virus of Gremmeniella abietina type B (Ascomycota: Helotiaceae) has a composite genome with endornavirus affinities. J. Gen. Vir. 2009, 90, 2299-2305. [CrossRef]

146. Botella, L.; Hantula, J. Description, Distribution, and Relevance of Viruses of the Forest Pathogen Gremmeniella abietina. Viruses 2018, 10, 654. [CrossRef]

147. Hillman, B.I.; Annisa, A.; Suzuki, N. Viruses of Plant-Interacting Fungi. Adv. Vir. Res. 2018, 100, 99-116. [CrossRef]

148. Eusebio-Cope, A.; Sun, L.; Hillman, B.I.; Suzuki, N. Mycoreovirus 1 S4-coded protein is dispensable for viral replication but necessary for efficient vertical transmission and normal symptom induction. Virology 2010, 397, 399-408. [CrossRef]

149. Hillman, B.I.; Supyani, S.; Kondo, H.; Suzuki, N. A reovirus of the fungus Cryphonectria parasitica that is infectious as particles and related to the coltivirus genus of animal pathogens. J. Virol. 2004, 78, 892-898. [CrossRef]

150. Doherty, M.; Coutts, R.H.A.; Brasier, C.M.; Buck, K.W. Sequence of RNA dependent RNA polymerase genes provides evidence for three more distinct mitoviruses in Ophiostoma novo-ulmi isolate Ld. Virus Genes 2006, 33, 41-44. [CrossRef] [PubMed]

151. Hintz, W.E.; Carneiro, J.S.; Kassatenko, I.; Varga, A.; James, D. Two novel mitoviruses from a Canadian isolate of the Dutch elm pathogen Ophiostoma novo-ulmi (93-1224). J. Virol. 2013, 10, 252. [CrossRef] [PubMed]

152. Kozlakidis, Z.; Brown, N.A.; Jamal, A.; Phoon, X.; Coutts, R.H. Incidence of endornaviruses in Phytophthora taxon douglasfir and Phytophthora ramorum. Virus Genes 2010, 40, 130-134. [CrossRef]

153. Poimala, A.; Parikka, P.; Hantula, J.; Vainio, E.J. Viral diversity in Phytophthora cactorum population infecting strawberry. Environ. Microbiol. 2021. [CrossRef] [PubMed]

154. Preisig, O.; Wingfield, B.D.; Wingfield, M.J. Coinfection of a fungal pathogen 1141 by two distinct double-stranded RNA viruses. Virology 1998, 252, 399-406. [CrossRef]

155. Sahin, E.; Akata, I. Full-length genome characterization of a novel alphapartitivirus detected in the ectomycorrhizal fungus Hygrophorus penarioides. Virus Genes 2021, 57, 94-99. [CrossRef] [PubMed]

156. Sahin, E.; Akata, I. Complete genome sequence of a novel mitovirus from the ectomycorrhizal fungus Geopora sumneriana. Arch. Virol. 2019, 164, 2853-2857. [CrossRef]

157. Gilbert, K.B.; Holcomb, E.E.; Allscheid, R.L.; Carrington, J.C. Hiding in plain sight: New virus genomes discovered via a systematic analysis of fungal public transcriptomes. PLOS ONE 2019, 14, e0219207. [CrossRef]

158. Sahin, E.; Keskin, E.; Akata, I. Molecular characterization of a novel partitivirus hosted by the false morel mushroom Gyromitra esculenta. Arch. Virol. 2021, 166, 1247-1251. [CrossRef] 
159. Sutela, S.; Vainio, E.J. Virus population structure in the ectomycorrhizal fungi Lactarius rufus and L. tabidus at two forest sites in Southern Finland. Virus Res. 2020, 285, 197993. [CrossRef] [PubMed]

160. Sahin, E.; Keskin, E.; Akata, I. Novel and diverse mycoviruses co-inhabiting the hypogeous ectomycorrhizal fungus Picoa juniperi. Virology 2021, 552, 10-19. [CrossRef] [PubMed]

161. Stielow, B.; Menzel, W. Complete nucleotide sequence of TaV1, a novel totivirus isolated from a black truffle ascocarp (Tuber aestivum Vittad.). Arch. Virol. 2010, 155, 2075-2078. [CrossRef]

162. Stielow, B.; Klenk, H.P.; Menzel, W. Complete genome sequence of the first endornavirus from the ascocarp of the ectomycorrhizal fungus Tuber aestivum Vittad. Arch. Virol. 2011, 156, 343-345. [CrossRef] [PubMed]

163. Stielow, B.; Klenk, H.P.; Winter, S.; Menzel, W. A novel Tuber aestivum (Vittad.) mitovirus. Arch. Virol. 2011, 156, 1107-1110. [CrossRef]

164. Stielow, J.B.; Bratek, Z.; Klenk, H.P.; Winter, S.; Menzel, W. A novel mitovirus from the hypogeous ectomycorrhizal fungus Tuber excavatum. Arch. Virol. 2012, 157, 787-790. [CrossRef] [PubMed]

165. Sahin, E.; Akata, I.; Keskin, E. Novel and divergent bipartite mycoviruses associated with the ectomycorrhizal fungus Sarcosphaera coronaria. Virus Res. 2020, 286, 198071. [CrossRef] [PubMed]

166. Arjona-Lopez, J.M.; Telengech, P.; Jamal, A.; Hisano, S.; Kondo, H.; Yelin, M.D.; Arjona-Girona, I.; Kanematsu, S.; Lopez-Herrera, C.J.; Suzuki, N. Novel, diverse RNA viruses from Mediterranean isolates of the phytopathogenic fungus, Rosellinia necatrix: Insights into evolutionary biology of fungal viruses. Environ. Microbiol. 2018, 20, 1464-1483. [CrossRef] [PubMed]

167. Milgroom, M.G.; Cortesi, P. Biological control of chestnut blight with hypovirulence: A critical analysis. Annu. Rev. Phytopathol. 2004, 42, 311-338. [CrossRef]

168. Rigling, D.; Prospero, S. Cryphonectria parasitica, the causal agent of chestnut blight: Invasion history, population biology and disease control. Mol. Plant Pathol. 2018, 19, 7-20. [CrossRef]

169. Kashif, M.; Jurvansuu, J.; Vainio, E.J.; Hantula, J. Alphapartitiviruses of Heterobasidion Wood Decay Fungi Affect Each Other's Transmission and Host Growth. Front Cell Infect Microbiol. 2019, 9, 64. [CrossRef] [PubMed]

170. Chiba, S.; Suzuki, N. Highly activated RNA silencing via strong induction of dicer by one virus can interfere with the replication of an unrelated virus. Proc. Natl. Acad. Sci. USA 2015, 112, E4911-E4918. [CrossRef]

171. Yaegashi, H.; Yoshikawa, N.; Ito, T.; Kanematsu, S. A mycoreovirus suppresses RNA silencing in the white root rot fungus, Rosellinia necatrix. Virology 2013, 444, 409-416. [CrossRef]

172. Sutela, S.; Forgia, M.; Vainio, E.J.; Chiapello, M.; Daghino, S.; Vallino, M.; Martino, E.; Girlanda, M.; Perotto, S.; Turina, M. The virome from a collection of endomycorrhizal fungi reveals new viral taxa with unprecedented genome organization. Virus Evol. 2020, 6. [CrossRef]

173. Lin, Y.-H.; Fujita, M.; Chiba, S.; Hyodo, K.; Andika, I.B.; Suzuki, N.; Kondo, H. Two novel fungal negative-strand RNA viruses related to mymonaviruses and phenuiviruses in the shiitake mushroom (Lentinula edodes). Virology 2019, 533, 125-136. [CrossRef]

174. Guo, M.; Shen, G.; Wang, J.; Liu, M.; Bian, Y.; Xu, Z. Mycoviral diversity and characteristics of a negative-stranded RNA virus LeNSRV1 in the edible mushroom Lentinula edodes. Virology 2021, 555, 89-101. [CrossRef]

175. Vainio, E.J.; Sutela, S. Mixed infection by a partitivirus and a negative-sense RNA virus related to mymonaviruses in the polypore fungus Bondarzewia berkeleyi. Virus Res. 2020, 286, 198079. [CrossRef]

176. Magae, Y.; Sunagawa, M. Characterization of a mycovirus associated with the brown discoloration of edible mushroom, Flammulina velutipes. J. Virol. 2010, 7, 342. [CrossRef] [PubMed]

177. Qiu, L.; Li, Y.; Liu, Y.; Gao, Y.; Qi, Y.; Shen, J. Particle and naked RNA mycoviruses in industrially cultivated mushroom Pleurotus ostreatus in China. Fungal Biol. 2010, 114, 507-513. [CrossRef]

178. Gibbs, D.; Chen, Y. The Red List of Maples Archived 2019-05-28 at the Wayback Machine; Botanic Gardens Conservation International (BGCI): Richmond, BC, Canada, 2009.

179. Binggeli, P. Sycamore lore. Plant Lore Notes News 1993, 29, 131-133.

180. Atanasoff, D. Old and new virus diseases of trees and shrubs. Phytopathol. Z. 1935, 8, 197-223.

181. Cooper, J.I. Virus Disease of Trees and Shrubs; Institute of Terrestrial Ecology, Natural Environment Research Council: Oxford, UK, 1979.

182. Esseen, P.; Ehnström, B.; Ericson, L.; Sjöberg, K. Boreal Forests. In Ecological Bulletins 1997, 46, $16-47$.

183. Hynynen, J.; Niemisto, P.; Vihera-Aarnio, A.; Brunner, A.; Hein, S.; Velling, P. Silviculture of birch (Betula pendula Roth and Betula pubescens Ehrh.) in Northern Europe. Forestry 2010, 83, 103-119. [CrossRef]

184. Dubois, H.; Verkasalo, E.; Claessens, H. Potential of Birch (Betula pendula Roth and B. pubescens Ehrh.) for Forestry and ForestBased Industry Sector within the Changing Climatic and Socio-Economic Context of Western Europe. Forests 2020, 11, 336. [CrossRef]

185. Rumbou, A.; von Bargen, S.; Jalkanen, R.; Büttner, C. Emergence of "birch-leafroll disease" in Fennoscandia correlated with significant changes in cherry leaf roll virus population. In Proceedings of the 47th Plant Virus Diseases Meet, Berlin, Germany, 16-17 March 2015; Humboldt-Universität zu Berlin: Berlin, Germany.

186. Rumbou, A.; von Bargen, S.; Jalkanen, R.; Büttner, C. The birch-leafroll disease emerging in forests and urban parks in Fennoscandia-viral agents associated with the disease. In Proceedings of the 18th International Plant Protection Congress (IPPC), Berlin, Germany, 24-27 August 2015. 
187. Jalkanen, R.; Buettner, C.; von Bargen, S. Cherry leaf roll virus abundant on Betula pubescens in Finland. Silva Fenn. 2007, 41, 755-762. [CrossRef]

188. Langer, J.; Rumbou, A.; Fauter, A.; von Bargen, S.; Buettner, C. High genetic variation in a small population of Cherry leaf roll virus in Betula sp., of montane origin in Corsica. For. Pathol. 2016, 46, 595-599. [CrossRef]

189. Opoku, E.B.; Landgraf, M.; Pack, K.; Bandte, M.; von Bargen, S.; Schreiner, M.; Jaekel, B.; Buettner, C. Emerging viruses in urban green- detection of the virome in birch (Betula sp.). J. Hortic. Biol. Sci. 2018, 5, 2. [CrossRef]

190. Rytkönen, A.; Lilja, A.; Petäistö, R.-L.; Hantula, J. Irrigation water and Phytophthora cactorum in a forest nursery. Scand. J. For. Res. 2008, 23, 404-411. [CrossRef]

191. Conedera, M.; Tinner, W.; Krebs, P.; de Rigo, D.; Caudullo, G. Castanea sativa in Europe: Distribution, habitat, usage and threats. In European Atlas of Forest Tree Species; San-Miguel-Ayanz, D., de Rigo, G., Caudullo, T., Houston Durrant, A., Mauri, J., Eds.; Publ. Off. EU: Luxembourg, 2016; pp. 78-79.

192. Gualaccini, G. Una virosi nuova del castagno. Boll. Staz. Patol. Veg. 1958, 16, 67-75.

193. Desvignes, J.C. Sweet chestnut incompatibility and mosaics caused by the chestnut mosaic virus (ChMV). Acta Hortic 1999, 494, 451-454. [CrossRef]

194. Antonaroli, R.; Perna, M.R. Una fitopatia ad eziologia ancora incerta: Il giallume dl castagno in Emilia Romagna e nelle Marche. Sherwood 2000, 6, 43-46.

195. Suzuki, N.; Cornejo, C.; Aulia, A.; Shahi, S.; Hillman, B.I.; Rigling, D. In-Tree Behavior of Diverse Viruses Harbored in the Chestnut Blight Fungus, Cryphonectria parasitica. J. Virol. 2021, 95. [CrossRef]

196. Schoebel, C.N.; Prospero, S.; Gross, A.; Rigling, D. Detection of a Conspecific Mycovirus in Two Closely Related Native and Introduced Fungal Hosts and Evidence for Interspecific Virus Transmission. Viruses 2018, 10, 628. [CrossRef] [PubMed]

197. Caudullo, G.; Tinner, W.; de Rigo, D. Picea abies in Europe: Distribution, habitat, usage and threats. In European Atlas of Forest Tree Species; San-Miguel-Ayanz, J., de Rigo, D., Caudullo, G., Houston Durrant, T., Mauri, A., Eds.; Publ. Off. EU: Luxembourg, 2016; p. $\mathrm{e} 012300+$.

198. Castello, J.D.; Rogers, S.O.; Bachand, G.D.; Fillhart, R.C.; Murray, J.S.; Weidemann, K.; Bachand, M.; Almond, M.A. Detection and partial characterization of tenuiviruses from black spruce. Plant Dis. 2000, 84, 143-147. [CrossRef] [PubMed]

199. Woodward, S.; Stenlid, J.; Karjalainen, R.; Hütterman, A. (Eds.) Heterobasidion Annosum: Biology, Ecology, Impact and Control; CAB International: Wallingford, UK, 1998.

200. Vainio, E.J.; Jurvansuu, J.; Hyder, R.; Kashif, M.; Piri, T.; Tuomivirta, T.; Poimala, A.; Xu, P.; Mäkelä, S.; Nitisa, D.; et al. Heterobasidion Partitivirus 13 Mediates Severe Growth Debilitation and Major Alterations in the Gene Expression of a Fungal Forest Pathogen. J. Virol. 2018, 92, e01744-17. [CrossRef] [PubMed]

201. Kozlakidis, Z.; Hacker, C.V.; Bradley, D.; Jamal, A.; Phoon, X.; Webber, J.; Brasier, C.M.; Buck, K.W.; Coutts, R.H.A. Molecular characterisation of two novel double-stranded RNA elements from Phlebiopsis gigantea. Virus Genes 2009, 39, 132-136. [CrossRef] [PubMed]

202. Petrzik, K.; Sarkisova, T.; Starý, J.; Koloniuk, I.; Hrabáková, L.; Kubešová, O. Molecular characterization of a new monopartite dsRNA mycovirus from mycorrhizal Thelephora terrestris (Ehrh.) and its detection in soil oribatid mites (Acari: Oribatida). Virology 2016, 489, 12-19. [CrossRef] [PubMed]

203. Rogers, P.; Pinno, B.D.; Šebesta, J.; Albrectsen, B.R.; Li, G.; Ivanova, N.; Kusbach, A.; Kuuluvainen, T.; Landhäusser, S.M.; Liu, H.; et al. A global view of aspen: Conservation science for widespread keystone systems. Glob. Ecol. Conserv. 2020, 21, e00828. [CrossRef]

204. Eaton, E.; Caudullo, G.; Oliveira, S.; de Rigo, D. Quercus robur and Quercus petraea in Europe: Distribution, habitat, usage and threats. In European Atlas of Forest Tree Species; San-Miguel-Ayanz, J., de Rigo, D., Caudullo, G., Houston Durrant, T., Mauri, A., Eds.; Publications Office of the EU: Luxembourg, 2016; p. e01c6df+.

205. Lorimer, C.G. The Decline of Oak Forests. BioScience 2003, 53, 915. [CrossRef]

206. Charlebois, D. Elderberry as a medicinal plant. In Issues in New Crops and New Uses; Janick, J., Whipkey, A., Eds.; ASHS Press: Alexandria, VA, USA, 2007; pp. 284-292.

207. McAllister, H.A. The Genus Sorbus: Mountain Ash and other Rowans; Royal Botanic Gardens Kew: Richmond, UK, 2005; ISBN 9781842460887.

208. Schmelzer, K. Proof of relationship between the origins of Cherry leaf roll virus and Elm mosaic virus]. Zent. Bakteriol. Parasitenkd. Infekt. Hyg. 1972, 127, 140-144.

209. Cole, T.E.; Mcller, B.M.; Hong, Y.; Brasier, C.M.; Buck, K.W. Complexity of Virus-like Double-stranded RNA Elements in a Diseased Isolate of the Dutch Elm Disease Fungus, Ophiostoma novo-ulmi. J. Phytopathol. 2008, 146, 593-598. [CrossRef]

210. Shamoun, S.F.; Varga, A.; Valverde, R.A.; Ramsfield, T.; Sumampong, G.; Elliott, M.; Masri, S.; James, D. Identification and molecular characterization of a new double-stranded RNA virus infecting Chondrostereum purpureum. Can. J. Plant Pathol. 2008, 30, 604-613. [CrossRef]

211. Sato, Y.; Miyazaki, N.; Kanematsu, S.; Xie, J.; Ghabrial, S.A.; Hillman, B.I.; Suzuki, N. ICTV Report Consortium. ICTV Virus Taxonomy Profile: Megabirnaviridae. J. Gen. Virol. 2019, 100, 1269-1270. [CrossRef]

212. Valverde, R.A.; Khalifa, M.E.; Okada, R.; Fukuhara, T.; Sabanadzovic, S. ICTV Report Consortium. ICTV Virus Taxonomy Profile: Endornaviridae. J. Gen. Virol. 2019, 100, 1204-1205. [CrossRef] 
213. Jiāng, D.; Ayllón, M.A.; Marzano, S.Y.L. ICTV Report Consortium. ICTV Virus Taxonomy Profile: Mymonaviridae. J. Gen. Virol. 2019, 100, 1343-1344. [CrossRef]

214. Massart, S.; Candresse, T.; Gil, J.; Lacomme, C.; Predajna, L.; Ravnikar, M.; Reynard, J.S.; Rumbou, A.; Saldarelli, P.; Škorić, D.; et al. A framework for the evaluation of biosecurity, commercial, regulatory and scientific impacts of plant viruses and viroids identified by NGS technologies. Front. Microbiol. 2017, 8, 45. [CrossRef]

215. Massart, S.; Candresse, T.; Gil, J.; Lacomme, C.; Predajna, L.; Ravnikar, M.; Reynard, J.S.; Rumbou, A.; Saldarelli, P.; Škorić, D.; et al. After the data deluge: Biological characterization of the new variants and viral species identified by NGS. In Proceedings of the International Congress of Plant Pathology (ICPP), Boston, MA, USA, 29 July-3 August 2018.

216. Rosenberg, E.; Zilber-Rosenberg, I. The hologenome concept of evolution after 10 years. Microbiome 2018, 6, 78. [CrossRef]

217. Yue, J.; Hu, X.; Huang, J. Horizontal gene transfer in the innovation and adaptation of land plants. Plant Signal Behav. 2013, 8, e24130. [CrossRef] [PubMed]

218. Maumus, F.; Epert, A.; Nogué, F.; Blanc, G. Plant genomes enclose footprints of past infections by giant virus relatives. Nat. Commun. 2014, 5, 4268. [CrossRef]

219. Geering, A.D.W.; Olszewski, N.E.; Harper, G.; Lockhart, B.E.L.; Hull, R.; Thomas, J.E. Banana contains a diverse array of endogenous badnaviruses. J. Gen. Virol. 2005, 86, 511-520. [CrossRef] [PubMed]

220. Borah, B.K.; Sharma, S.; Kant, R.; Anthony-Johnson, A.M.; Saigopal, D.V.R.; Dasgupta, I. Bacilliform DNA-containing plant viruses in the tropics: Commonalities within a genetically diverse group. Mol. Plant Pathol. 2013, 14, 759-771. [CrossRef] [PubMed]

221. Liu, H.; Fu, Y.; Jiang, D.; Li, G.; Xie, J.; Cheng, J.; Peng, Y.; Ghabrial, S.A.; Yi, X. Widespread Horizontal Gene Transfer from Double-Stranded RNA Viruses to Eukaryotic Nuclear Genomes. J. Virol. 2010, 84, 11876-11887. [CrossRef]

222. Jo, Y.; Lian, S.; Chu, H.; Cho, J.K.; Yoo, S.H.; Choi, H.; Yoon, J.Y.; Choi, S.K.; Lee, B.C.; Cho, W.K. Peach RNA viromes in six different peach cultivars. Sci. Rep. 2018, 8, 1844. [CrossRef]

223. Coetzee, B.M.; Freeborough, J.; Maree, H.J.J.; Celton, M.; Rees, J.G.; Burger, J.T. Deep sequencing analysis of viruses infecting grapevines: Virome of a vineyard. Virology 2010, 400, 157-163. [CrossRef]

224. Beuve, M.; Hily, J.M.; Alliaume, A.; Reinbold, C.; Le Maguet, J.; Candresse, T.; Herrbach, E.; Lemaire, O. A complex virome unveiled by deep sequencing analysis of RNAs from a French Pinot Noir grapevine exhibiting strong leafroll symptoms. Arch. Virol. 2018, 163, 2937-2946. [CrossRef]

225. Sun, L.; Nuss, D.L.; Suzuki, N. Synergism between a mycoreovirus and a hypovirus mediated by the papain-like protease p29 of the prototypic hypovirus CHV1-EP713. J. Gen. Virol. 2006, 87, 3703-3714. [CrossRef]

226. Hisano, S.; Zhang, R.; Faruk, M.I.; Kondo, H.; Suzuki, N. A neo-virus lifestyle exhibited by a (+)ssRNA virus hosted in an unrelated dsRNA virus: Taxonomic and evolutionary considerations. Virus Res. 2018, 244, 75-83. [CrossRef]

227. Wu, S.; Cheng, J.; Fu, Y.; Chen, T.; Jiang, D.; Ghabrial, S.A.; Xie, J. Virus-mediated suppression of host non-self recognition facilitates horizontal transmission of heterologous viruses. PLoS Pathog. 2017, 13, e1006234. [CrossRef]

228. Liu, Y.C.; Linder-Basso, D.; Hillman, B.I.; Kaneko, S.; Milgroom, M.G. Evidence for interspecies transmission of viruses in natural populations of filamentous fungi in the genus Cryphonectria. Mol. Ecol. 2003, 12, 1619-1628. [CrossRef]

229. Shi, M.; Lin, X.D.; Tian, J.H.; Chen, L.J.; Chen, X.; Li, C.X.; Qin, X.C.; Li, J.; Cao, J.P.; Eden, J.S.; et al. Redefining the invertebrate RNA virosphere. Nature 2016, 540, 539-543. [CrossRef] [PubMed]

230. Roossinck, M.J. Evolutionary and ecological links between plant and fungal viruses. New Phytol. 2019, 221, 86-92. [CrossRef]

231. Domínguez-Díaz, C.; García-Orozco, A.; Riera-Leal, A.; Padilla-Arellano, J.R.; Fafutis-Morris, M. Microbiota and Its Role on Viral Evasion: Is It With Us or Against Us? Front Cell Infect Microbiol. 2019, 9, 256. [CrossRef] [PubMed]

232. Massart, S.; Martinez-Medina, M.; Jijakli, M.H. Biological control in the microbiome era: Challenges and opportunities. Biol. Control. 2015, 89, 98-108. [CrossRef]

233. Chiba, S.; Lin, Y.-H.; Kondo, H.; Kanematsu, S.; Suzuki, N. A novel betapartitivirus RnPV6 from Rosellinia necatrix tolerates host RNA silencing but is interfered by its defective RNAs. Virus Res. 2016, 219, 62-72. [CrossRef]

234. Salaipeth, L.; Chiba, S.; Eusebio-Cope, A.; Kanematsu, S.; Suzuki, N. Biological properties and expression strategy of rosellinia necatrix megabirnavirus 1 analysed in an experimental host, Cryphonectria parasitica. J. Gen. Virol. 2014, 95, 740-750. [CrossRef]

235. Kanematsu, S.; Arakawa, M.; Oikawa, Y.; Onoue, M.; Osaki, H.; Nakamura, H.; Ikeda, K.; Kuga-Uetake, Y.; Nitta, H.; Sasaki, A.; et al. A Reovirus Causes Hypovirulence of Rosellinia necatrix. Phytopathology 2004, 94, 561-568. [CrossRef] [PubMed]

236. Chiba, S.; Salaipeth, L.; Lin, Y.H.; Sasaki, A.; Kanematsu, S.; Suzuki, N. A novel bipartite double-stranded RNA Mycovirus from the white root rot Fungus Rosellinia necatrix: Molecular and biological characterization, taxonomic considerations, and potential for biological control. J. Virol. 2009, 83, 12801-12812. [CrossRef] [PubMed]

237. Sasaki, A.; Nakamura, H.; Suzuki, N.; Kanematsu, S. Characterization of a new megabirnavirus that confers hypovirulence with the aid of a co-infecting partitivirus to the host fungus, Rosellinia necatrix. Virus Res. 2016, 219, 73-82. [CrossRef]

238. Suzuki, N. Frontiers in fungal virology. J. Gen. Plant Pathol. 2017, 83, 419-423. [CrossRef]

239. Martemyanov, V.V.; Bakhvalov, S.A.; Rantala, M.J.; Dubovskiy, I.M.; Shul'ts, E.E.; Belousova, I.A.; Strel'nikov, A.G.; Glupov, V.V. The response of gypsy moth (Lymantria dispar L.) larvae infected with nuclear polyhedrosis virus to induced resistance in birch (Betula pendula Roth.). Russ. J. Ecol. 2009, 40, 434-439. [CrossRef]

240. Roden, D.B.; Mattson, W.J. Rapid induced resistance and host species effects on gypsy moth, Lymantria dispar (L.): Implications for outbreaks on three tree species in the boreal forest. For. Ecol. Manag. 2008, 255, 1868-1873. [CrossRef] 
241. Castro, M.; Melo, F.L.; Tagliari, M.; Inglis, P.W.; Craveiro, S.R.; Ribeiro, Z.; Ribeiro, B.M.; Báo, S.N. The genome sequence of Condylorrhiza vestigialis NPV, a novel baculovirus for the control of the Alamo moth on Populus spp. in Brazil. J. Invert. Pathol. 2017, 148, 152-161. [CrossRef]

242. Thumbi, D.K.; Eveleigh, R.J.; Lucarotti, C.J.; Lapointe, R.; Graham, R.I.; Pavlik, L.; Lauzon, H.A.; Arif, B.M. Complete sequence, analysis and organization of the Orgyia leucostigma nucleopolyhedrovirus genome. Viruses 2011, 3, 2301-2327. [CrossRef]

243. Brodersen, G.; Johns, R.; Lapointe, R.; Thumbi, D.; Thurston, G.; Lucarotti, C.; Quiring, D. Larval diet prior to and following virus ingestion influences the efficacy of two nucleopolyhedroviruses in whitemarked tussock moth (Orgyia leucostigma) caterpillars. Can. Entomol. 2012, 144, 447-457. [CrossRef]

244. Graves, R.; Quiring, D.T.; Lucarotti, C.J. Transmission of a Gammabaculovirus within Cohorts of Balsam Fir Sawfly (Neodiprion abietis) Larvae. Insects 2012, 3, 989-1000. [CrossRef]

245. Solter, L.F.; Hajek, A.E.; Lacey, L.A. Exploration for Entomopathogens. In Microbial Control of Insect and Mite Pests: From Theory to Practice; Lacey, L., Ed.; Academic Press: Cambridge, MA, USA, 2017; pp. 13-23. [CrossRef]

246. Koonin, E.; Dolja, V.; Krupovic, M. The healthy human virome: From virus-host symbiosis to disease. Curr. Opinion Virol. 2021, 47, 86-94. [CrossRef]

247. Engering, A.; Hogerwerf, L.; Slingenbergh, J. Pathogen-host-environment interplay and disease emergence. Emerg. Microbes Infect. 2013, 2, 1-7. [CrossRef] [PubMed] 